\title{
Liberia: Second Review of Performance Under the Staff-Monitored Program and New Program for 2007
}

This paper on the Second Review Under the Staff Monitored Program and New Program for 2007 for Liberia was prepared by a staff team of the International Monetary Fund as background documentation for the periodic consultation with the member country. It is based on the information available at the time it was completed on January 18,2007. The views expressed in this document are those of the staff team and do not necessarily reflect the views of the government of Liberia or the Executive Board of the IMF.

The policy of publication of staff reports and other documents by the IMF allows for the deletion of market-sensitive information.

To assist the IMF in evaluating the publication policy, reader comments are invited and may be sent by e-mail to publicationpolicy@imf.org.

\author{
Copies of this report are available to the public from \\ International Monetary Fund • Publication Services \\ 700 19th Street, N.W. • Washington, D.C. 20431 \\ Telephone: (202) 6237430 • Telefax: (202) 6237201 \\ E-mail: publications@imf.org • Internet: http://www.imf.org \\ Price: $\$ 18.00$ a copy

\section{International Monetary Fund \\ Washington, D.C.}



INTERNATIONAL MONETARY FUND

LIBERIA

\title{
Second Review of Performance Under the Staff-Monitored Program and New Program for 2007
}

\author{
Prepared by the African Department \\ (In consultation with other departments)
}

Approved by David Andrews and Michael Hadjimichael

January 18, 2007

\begin{abstract}
Discussions for the second review of performance under the February-September 2006 staffmonitored program (SMP) took place in Monrovia November 6-17, 2006. The staff team comprised Mr. Powell (head), Mr. Erasmus, and Mr. Leichter (all AFR), Mr. Rodriguez (PDR), Ms. Wong (FIN), and Mr. Tharkur (resident representative). The mission overlapped with an FAD mission on public revenue administration, an STA mission on monetary statistics, and an MCM mission on bank restructuring. Mr. Mamba, advisor to the Executive Director, and staff from the World Bank and African Development Bank participated in some discussions.
\end{abstract}

The mission met the Minister of Finance, the Acting Minister of Planning and Economic Affairs, the Governor of the Central Bank of Liberia (CBL), and other senior government officials as well as with the donor community and representatives of the legislature and the private sector. The staff also briefed President Johnson-Sirleaf on the mission's preliminary findings.

The Executive Board was informed of the first review of performance under the SMP on October 2, 2006 (Country Report No. 06/412). Executive Directors welcomed the progress the authorities had made in implementing their economic program and decided to initiate the deescalation of remedial measures the Fund had been applying against Liberia and to lift the declaration of noncooperation in place since March 30, 1990.

Understandings were reached on a new SMP to end 2007. This report describes the authorities' program and the policies to be monitored under the program. The authorities' letter of intent and memorandum of economic and financial policies (MEFP) for the SMP are attached.

A donor conference, co-hosted by the United Nations, the European Commission, the World Bank, the IMF, the African Development Bank and the United States, is scheduled for February 13-15, 2007 in Washington, DC. 


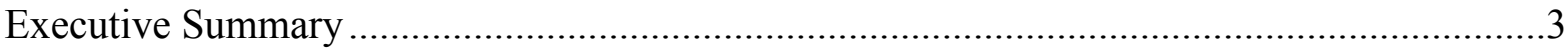

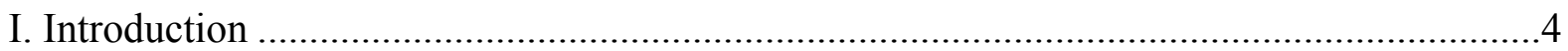

II. Recent Economic Developments and Performance Under the SMP ...............................4

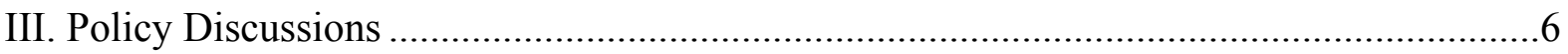

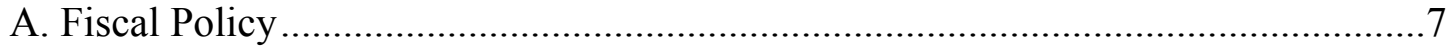

B. Monetary and Financial Sector Policies.......................................................... 10

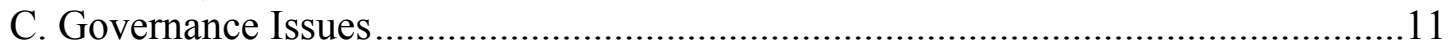

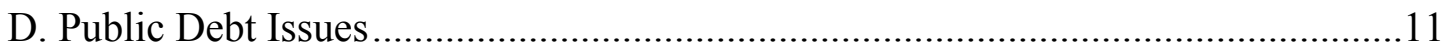

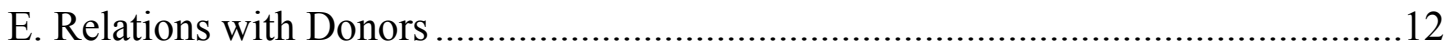

F. Technical Assistance and Data Issues ........................................................ 13

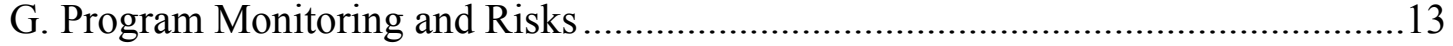

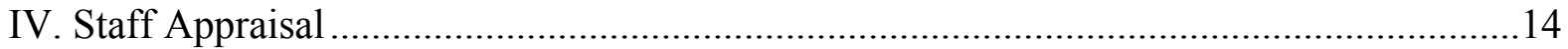

\section{Tables}

1. Selected Economic and Financial Indicators, 2003-07 ................................................19

2. Balance of Payments, 2003-07 ........................................................................................20

3. Summary of Central Government Operations, 2002/03-2006/07 ..................................21

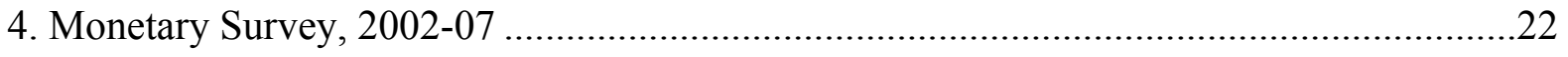

5. Liberia: Core Set of Financial Soundness Indicators, 2003-06 ....................................23

Figures

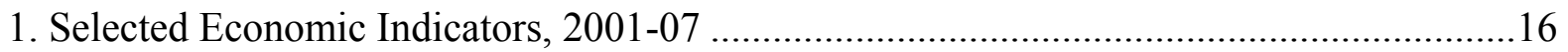

2. Exchange Rate Developments, January 2000-November 2006.....................................18

\section{Boxes}

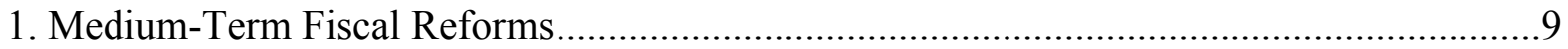

\section{Appendices}

I. Letter of Intent

Attachment I. Memorandum of Economic and Financial Policies ....................................26

Attachment II. Technical Memorandum of Understanding ..............................................40 


\section{EXECUTIVE SUMMARY}

- SMP Performance. Performance under the SMP in the quarter to end-September was mixed. The authorities achieved all but one of the quantitative benchmarks, but they needed more time to achieve key structural benchmarks, including the review of contracts and concessions and finalization of the domestic debt and anticorruption strategies. Most of these outstanding benchmarks have now been met.

- Recent developments. The post-war recovery continued in 2006, with real GDP growth estimated to have risen to $73 / 4$ percent from $5 \frac{1}{2}$ percent in 2005 . Inflation has remained in the single digits. The trade account deficit rose because of a substantial increase in imports.

- Macroeconomic policies. Fiscal policy has remained anchored on the need to maintain a balanced cash-based budget. Reflecting continued efforts to strengthen tax and customs administration, revenues, excluding grants, rose by 82 percent in the first five months of 2006/07 over the same period a year ago. Although the pace of public expenditure picked up after the budget's late approval in August, the balance in the government's accounts at the CBL at end-November was about US\$30 million. Monetary policy was geared to keeping inflation in the single digits by aiming at maintaining broad nominal exchange rate stability.

- Donor relations. Liberia's reconstruction requires continued significant external financial and technical support. Donor funds are spent almost entirely outside the government budget. Sustained progress with improving governance and strengthening budget planning and implementation would facilitate a reallocation of donor support to the budget and mobilize additional assistance to address critical development needs.

- New SMP. Understandings were reached on a new SMP to year-end 2007. The program is consistent with the authorities' draft interim Poverty Reduction Strategy Paper (IPRSP). It aims to further improve economic governance, public financial management (PFM), tax and customs administration, and the health of the banking sector. The program continues to focus on maintaining low inflation by targeting a broadly stable exchange rate. The staff considers that the authorities' program meets the standards of upper credit tranche conditionality and therefore provides a sound basis for quickly agreeing on a rights accumulation program (RAP), inter alia, when financing assurances for debt relief have been obtained.

- Political developments and key risks. Although the program for 2007 has strong ownership, it is ambitious and is subject to considerable risks. The main risks arise from significant capacity constraints at ministries and continued tension between the government and opposition-led legislature. 


\section{INTRODUCTION}

1. After assuming office on January 16, 2006, the government of President Johnson-Sirleaf quickly acted to strengthen economic performance. It endorsed the Governance and Economic Management Assistance Program (GEMAP) agreed to by the National Transitional Government of Liberia (NTGL) and international donors in September 2005, agreed with Fund staff on an SMP for February-September 2006, and adopted a 150-Day Action Plan. More recently the government drafted an I-PRSP.

2. The Fund's immediate strategy for Liberia recognizes the need to build capacity and strengthen economic institutions. Fund technical assistance is being offered in the Fund's areas of expertise (Informational Appendix III). The strategy recognizes that Liberia's external debt is unsustainable. However, the financing assurances needed for Liberia to enter into a RAP and ultimately benefit from the HIPC Initiative and MDRI-type relief are currently not available. Understandings have therefore been reached on a new SMP for 2007 that would provide a sound basis for moving rapidly to a RAP once financing assurances are in place.

\section{ReCENT ECONOMIC DEVELOPMENTS AND PERformance UndeR THE SMP}

\section{Supported by} continued peace and a large donor presence, Liberia's postwar economic recovery gathered momentum in 2006. Stronger growth in services (mostly construction) offset a sharper-than-projected decline in rubber production. Real GDP growth rose to an estimated $73 / 4$ percent in 2006 , from $5 \frac{1}{2}$ percent

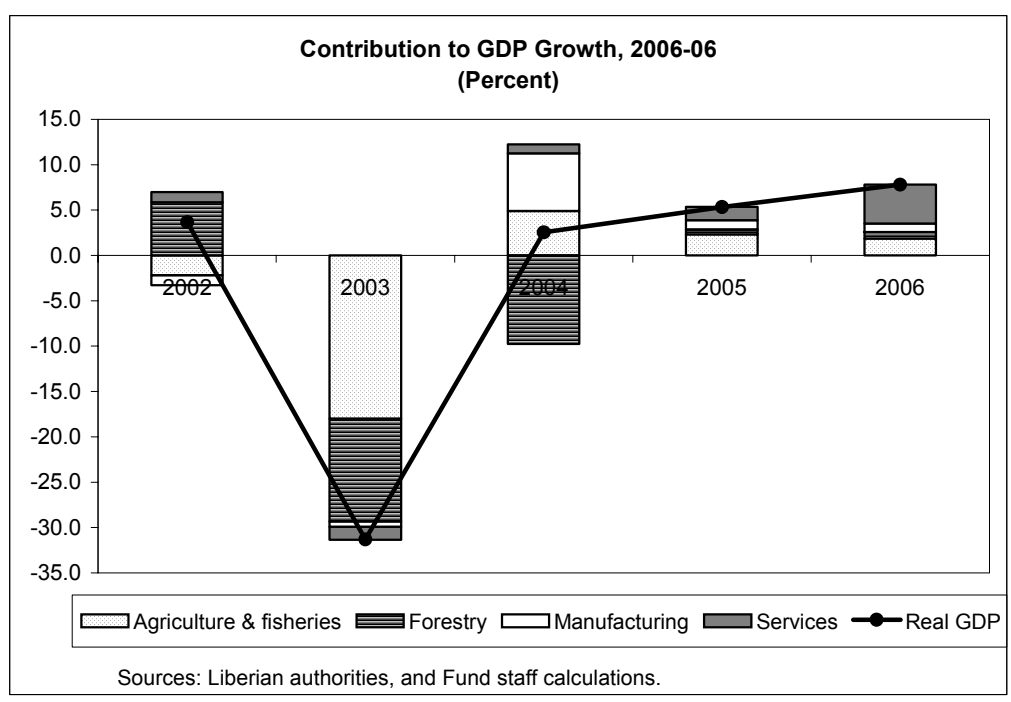
in 2005. 
4. Anchored by a relatively stable exchange rate, inflation was in single digits through October. Yearon-year inflation was

5.9 percent in October 2006, compared with 7.0 percent at year-end 2005.

5. The trade balance, however, deteriorated, despite much improved terms of trade. Buoyed by the recent economic recovery and donor activity, along with concerns about rice supplies, imports rose sharply. Nevertheless, the CBL's net liquid foreign exchange reserves continued to increase moderately, reaching about one-half of monthly imports.

\section{Continued strong} monetary growth has been concentrated in dollardenominated liabilities.

Guided by the objective of a stable exchange rate, reserve money growth was reduced to 17.2 percent in October, from 31.9 percent in April. The growth in Liberian dollar broad money (percentage of beginning period broad money) slowed to 9.5 percent in October 2006, from 13.5 percent in January.
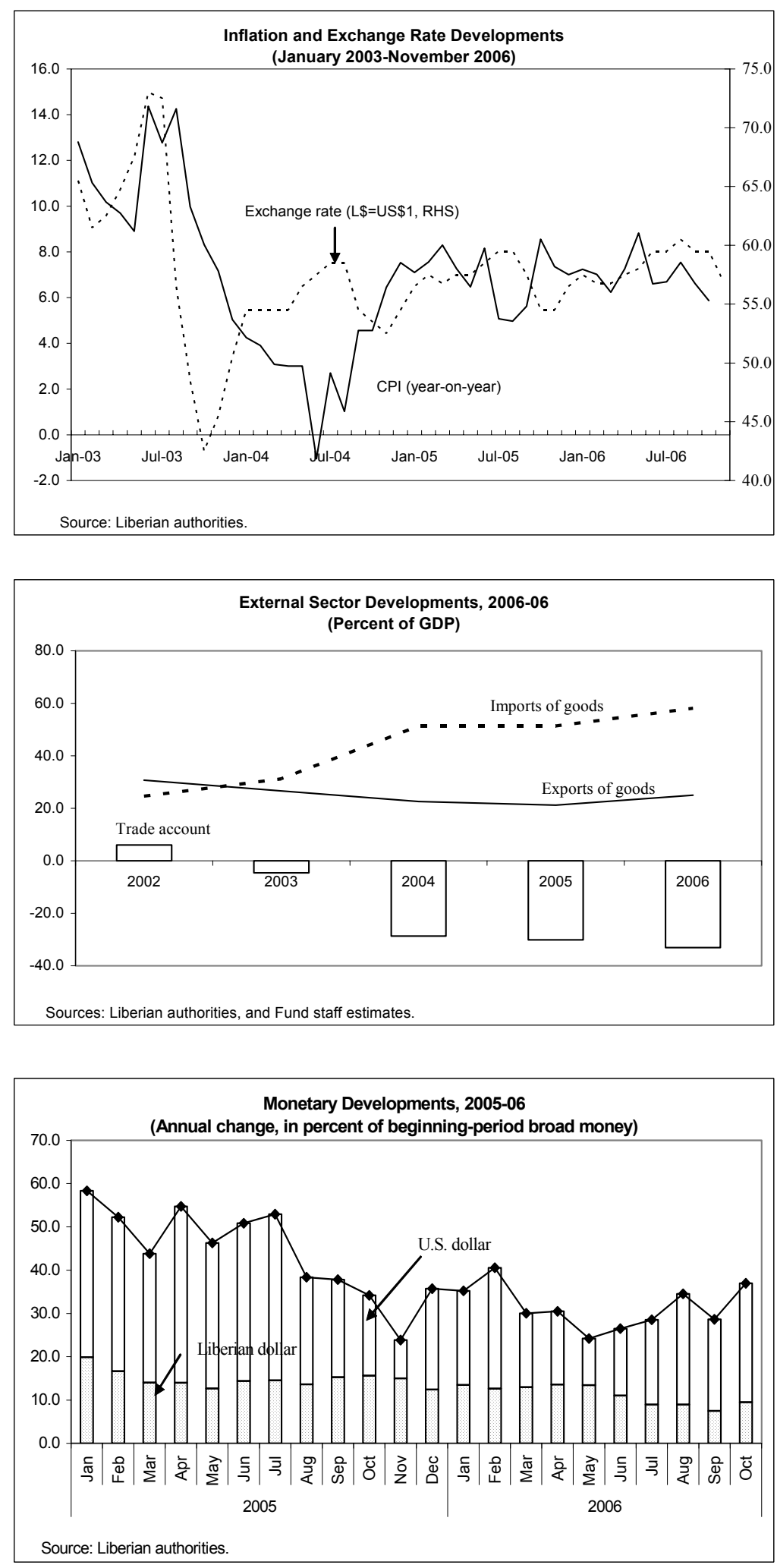
7. Fiscal management continued to improve in $\mathbf{2 0 0 6}$, although the pace of public expenditure is still slow. Revenues (excluding grants) in the first five months of fiscal year 2006/07 were 82 percent higher than a year ago. ${ }^{1}$ Total revenue through November was broadly consistent with the government's 2006/07 revenue target (US\$120.9 million). Though spending approvals

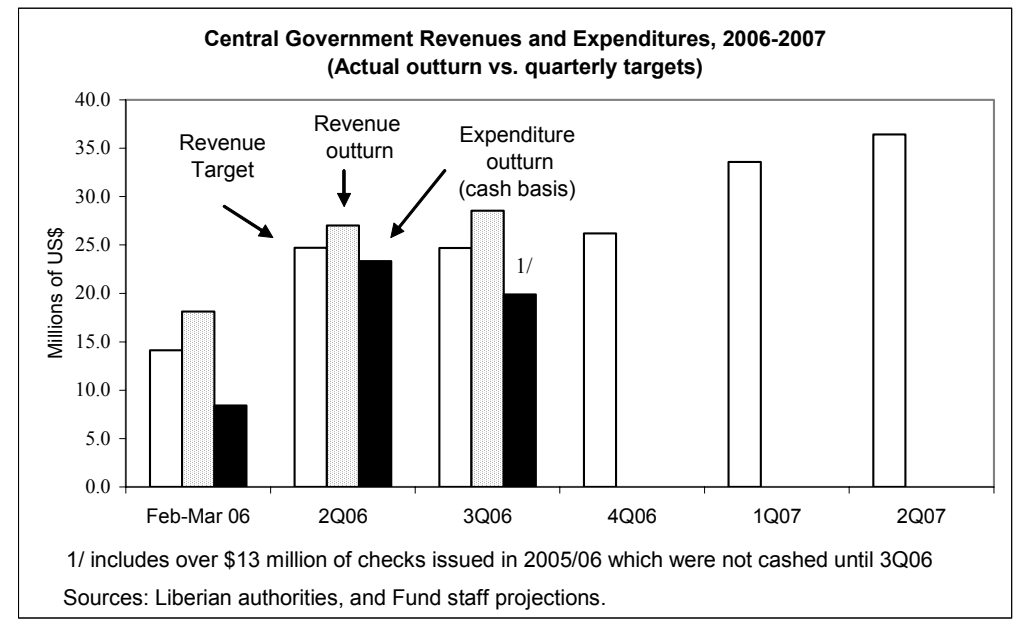
accelerated after August, there were still some delays in preparing and processing expenditure requests. The government still had approximately US\$30 million in its accounts at the CBL at the end of November.

8. Performance under the SMP in the quarter to end-September was mixed. The authorities achieved all but one quantitative benchmark for end-September (Table 1, Appendix I). They needed more time, however, to reach the outstanding June and September structural benchmarks (Table 2, Appendix I), which include: (i) finalizing a domestic debt resolution strategy, (ii) completing the review of contracts and concessions, and (iii) finalizing an anticorruption strategy. The authorities have made significant progress and are confident they can achieve these benchmarks by end-January 2007.

\section{Policy Discussions}

9. The government has prepared a draft I-PRSP for July 2006 to June 2008. The draft I-PRSP comprises four pillars: (i) national security; (ii) economic revitalization; (iii) governance and the rule of law; and (iv) infrastructure and basic services. ${ }^{2}$

10. The authorities' economic reform program for $\mathbf{2 0 0 7}$ is consistent with the draft I-PRSP and builds on progress made by the government in its first year. Appendix I presents the authorities' MEFP (key elements of their program are described in paragraphs 10-34). The program aims to maintain macroeconomic stability, further strengthen both PFM and the banking sector, and implement the government's anticorruption and domestic debt resolution strategies.

\footnotetext{
${ }^{1}$ This reflected a strong increase in tax receipts from international trade and nontax revenues.

${ }^{2}$ The I-PRSP is expected to be finalized shortly, and a JSAN will then be prepared.
} 


\section{The economic outlook for $\mathbf{2 0 0 7}$ is broadly favorable, with real GDP growth} supported by a broad-based recovery in agriculture, manufacturing, and services. The lifting of UN timber sanctions in 2006 is not expected to affect growth until timber production resumes in late 2007 (once institutional arrangements are in place). Despite a projected worsening terms of trade in 2007 , the trade balance is projected at about the same level as in 2006 as rice imports are expected to return to the historical average. The overall balance of payments deficit is expected to be more than fully financed by further arrears accumulation, allowing the CBL's net liquid foreign exchange reserves to increase slightly in 2007 , to about one month of imports.

\begin{tabular}{|c|c|c|c|}
\hline \multicolumn{4}{|l|}{ Liberia: Selected Economic Indicators, 2005-07 } \\
\hline & $\begin{array}{c}2005 \\
\text { Est. }\end{array}$ & $\begin{array}{r}2006 \\
\text { Est. }\end{array}$ & $\begin{array}{l}2007 \\
\text { Proj. }\end{array}$ \\
\hline Real GDP growth (percentage change) & 5.3 & 7.8 & 7.9 \\
\hline Agriculture (percentage change) & 5.0 & 4.1 & 6.4 \\
\hline Non-agriculture (percentage change) & 5.6 & 11.0 & 9.1 \\
\hline Average annual inflation & 6.9 & 7.5 & 7.0 \\
\hline Government revenues (percent of GDP) & 14.6 & 16.5 & 19.7 \\
\hline Trade balance (percent of GDP) & -30.2 & -33.1 & -31.4 \\
\hline CBL's net foreign exchange position (months of imports of goods and services) & 0.2 & 0.5 & 0.8 \\
\hline Terms of trade (percentage change; deterioration -) & 4.2 & 32.2 & -7.4 \\
\hline
\end{tabular}

\section{A. Fiscal Policy}

\section{Public revenues are expected to rise by 43 percent in $2006 / 07$ to 18.6 percent of}

GDP. ${ }^{3}$ To meet this target, the authorities indicated they would pursue measures to improve tax and customs administration by (i) further strengthening the large taxpayers unit (LTU), (ii) implementing the new taxpayer identification system, and (iii) further reducing tax exemptions. As the authorities noted, the reorganization of domestic tax revenue administration on the basis of taxpayer segmentation, and other PFM measures being carried out with Fund technical assistance should also help in this regard (Box 1). ${ }^{4}$ Moreover, implementation of a new tax identification number (which is also used in the new single

\footnotetext{
${ }^{3}$ See Country Report No. 06/412 for detail on the projected revenue increase. The revenue-to-GDP ratio should be interpreted with caution since Liberia's nominal GDP may be underestimated by limited data on economic activity, particularly the informal sector.

${ }^{4}$ The new organizational structure for the administration of domestic taxation creates bureaus of Large, Medium, and Small Taxpayers with their own operational units for taxpayer services, returns and payments, collection enforcement, and audit. The previous structure was along functional lines.
} 
administrative document for customs declarations) should improve tax and customs collection. The authorities also expect to boost revenue through the completed contracts and concessions review and efforts to stem tax exemption abuse among nongovernmental organizations.

\section{The authorities concurred with the staff on the need to review the Liberia} Revenue Code (LRC) and the investment code. Unclear regulations and ad hoc tax exemptions for individual investors have made tax administration more complex and have reduced the tax base. The authorities agreed, and noted that following the recent review of the LRC with technical assistance from the Fund, they would clarify the validity of existing regulations; they also plan to submit to the legislature an administrative procedures law, so that future regulations are issued in accordance with international best practices. The authorities also noted that a comprehensive reform of the investment code, designed to restrict tax exemptions to those in the LRC, is under way.

\section{The authorities recognize that to implement a cash-based balanced budget in} fiscal year 2006/07 they need to adhere to the prioritized monthly cash plans prepared by line ministries. While there is a sizeable balance in the government's accounts at the $\mathrm{CBL}$, revenue projections are subject to uncertainty. The authorities noted that revised monthly cash plans prioritizing expenditures - created by line ministries - are guiding monthly allotments. These plans and the public procurement law have improved public expenditure management; but the pace of spending is still slow. The staff urged the authorities to remove bottlenecks in approving expenditure (without weakening the interim commitment control system) and emphasized the potential gains of integrating the Bureau of the Budget $(\mathrm{BoB})$ into the Ministry of Finance. To address this issue, the authorities said that line ministries are being offered training on procurement procedures. Legislation to integrate the BoB into the Ministry of Finance, submitted to the legislature in September, is expected to be considered in the 2007 legislative session.

\section{The staff underlined the importance of finalizing the calendar for preparation of} the 2007/08 budget to ensure timely submission to the legislature. As stressed in preliminary discussions on the 2007/08 revenue outlook, the authorities will need to continue targeting a cash-based balanced budget. The staff also underscored the importance of strengthening macro-fiscal analysis by developing multiyear expenditure and revenue projections and by gathering data on potential donor flows. The authorities noted they are implementing a final budget calendar (which calls for budget submission to the legislature by mid-May), and are strengthening the macro fiscal analysis unit of the Ministry of Finance. This will allow commitments made at the planned February 2007 donor conference to be incorporated into the authorities' budget planning. 


\section{Box 1. Liberia: Medium-Term Fiscal Reforms}

Fund technical assistance (TA) to Liberia has covered PFM, tax policy, revenue administration, legal assistance related to the Liberia Revenue Code (LRC) and statistical reporting. Important recommendations have already been implemented, though there is still a full agenda. ${ }^{5}$

PFM - Implementation of selected recommendations has strengthened the interim commitment control system. Longer-term challenges include collecting and integrating donor aid data into the budget; moving to a multiyear budget framework, including a medium-term expenditure framework; and strengthening the auditing of line ministries to monitor budget execution and ensure more consistent and comprehensive budget reporting. Also, strengthening the macro fiscal unit at the Ministry of Finance would be critical to improving budget preparation and reporting. FAD has appointed a resident PFM advisor to support many of these reforms.

Tax policy - Recommendations have focused on broadening the tax base, including through lower corporate and income tax rates; planning for a review of tax laws, incentives, and import duty exemptions; and developing a sustainable investment incentive scheme consistent with the LRC. A number of recommendations on the general sales tax, excise rates, and customs tariffs were incorporated in the 2006/07 budget. ${ }^{6}$ LEG is providing TA for reforms of the LRC, including clarifying associated regulations.

Tax and customs administration -TA has stressed the need to reorganize domestic tax administration by taxpayer segmentation, implement a modern taxpayer identification system, and strengthen the LTU, including its auditing unit. FAD has provided follow-up peripatetic experts in tax administration starting in October 2006. For customs, FAD recommended reforms to modernize administration. If the authorities opted to increase private sector involvement in customs administration, the staff recommended that the authorities have a clear strategy phasing out such involvement in the medium term, once capacity grows.

Statistics - TA has focused on steps needed for conversion from the GFSM 1986 to GFSM 2001. Staff has provided a bridge table for conversion of existing codes to GFSM 2001 classification and emphasized the importance of coordinating implementation with IFMIS.

Under the GEMAP, internationally recruited experts have been placed at various fiscal agencies (including the Cash Management Committee (CMCo), the BoB, and the Ministry of Finance) to strengthen revenue administration and PFM. Plans are in place for the World Bank to provide additional advisors to support further capacity building at the Ministry of Finance; the EU will provide advisors to strengthen customs administration and public sector auditing; the USA will provide support to the BoB and the General Services Agency; and the UK will provide support on a comprehensive civil service reform program.

\footnotetext{
${ }^{5}$ Measures taken include submission of monthly cash plans by line ministries, implementation of tariff rate and exemption recommendations, and initial steps in implementing GFSM 2001.

${ }^{6}$ The authorities reduced the import tariff on notebooks from 45 percent to 5 percent, increased the excise on cigarettes to 15 percent, established a uniform excise on domestically produced and imported alcoholic beverages, and replaced the specific duty on zinc metal roofing sheets with an ad valorem rate of 5 percent.
} 


\section{The staff welcomed efforts to enhance transparency, including dissemination of} the preliminary report on implementing the $\mathbf{2 0 0 5 / 0 6}$ budget on the Finance Ministry's website. The staff also encouraged the authorities to publish monthly revenue and expenditure outturns. The authorities noted that regular dissemination of monthly revenue outturns has already commenced, and that publication of expenditure outturns would commence shortly.

\section{B. Monetary and Financial Sector Policies}

17. The monetary program for $\mathbf{2 0 0 7}$ aims to maintain single-digit inflation. Given the high degree of dollarization, the CBL will continue to use the exchange rate as the main indicator of domestic monetary conditions and gear its management of Liberian dollar liquidity toward maintaining broad nominal exchange rate stability. ${ }^{7}$ The staff, in welcoming progress in strengthening the monetary policy framework, encouraged the authorities to use the revised liquidity monitoring framework and to implement the revised foreign exchange auction rules. ${ }^{8}$ The staff also stressed the importance of maintaining the biweekly foreign exchange auctions and encouraged the authorities to assess the rules and procedures for using credit and supply auctions that could be used to supply or withdraw Liberian dollar liquidity on a short-term basis.

\section{The authorities indicated a desire to encourage de-dollarization of the economy.}

They, however, agreed with the staff that this process should be market driven, and would be supported by macroeconomic stability, a strengthened banking sector, and peace and stability. The staff suggested the following interim measures could support Liberian dollar demand: (i) introducing higher denomination bank notes; (ii) improving the quality of local bank notes; and (iii) reporting public revenue and expenditure in Liberian dollars.

\section{Liberia's banking system remains severely undercapitalized and fragile}

(Table 5). The staff urged the authorities to carry out plans to restructure all remaining undercapitalized banks, taking into account the government's domestic debt resolution strategy, and encouraged them to implement their new framework for resolving abandoned and nonoperating banks. Noting the authorities' desire to remove the moratorium on issuing new bank licenses, the staff acknowledged the small size and limited coverage of the five

\footnotetext{
${ }^{7}$ The monetary framework, which was formulated with MFD technical assistance, recognizes that in the highly dollarized and open economy, the exchange rate is the main transmission mechanism through which monetary imbalances affect prices.

${ }^{8}$ The revised auction rules (i) provide for purchase auctions; (ii) emphasize the CBL's discretion to reject outlier bids, even though the full auctioned sum has not been allocated; (iii) regulate the nature of foreign exchange bureau participation in the auctions; (iv) change the deadline for the submission of bids to the current practice of 9:30 am on the day of the auction; and (v) amend the maximum bid from a fixed amount to a percentage of the sum offered for auction.
} 
operating banks. However, the staff urged them to be cautious in licensing new banks in view of the limited capacity of the regulatory authority, and to consider issuing new licenses only to internationally reputable banks. The staff also urged the authorities to consult with them if new bank licenses are considered.

20. The CBL faces significant control and safeguards challenges. The chief administrator has supported adherence to, and strengthening of, existing internal controls. As CBL activity increases, however, the authorities will need to establish a comprehensive system of controls to safeguard the bank's resources and monetary data quality. In this context, the CBL's adoption of the International Financing Reporting Standards as its financial reporting framework (as recommended by the Fund's safeguards assessment mission) is encouraging. The staff also urged the authorities to bring the auditing of the CBL's 2006 accounts to a close, and to adopt clear audit selection criteria and rotation procedures to ensure that an internationally reputable firm conducts future audits. The authorities agreed, and noted that the audit is targeted for completion by end-March 2007 and that formal audit selection criteria and rotation procedures would be submitted to the CBL's Board for approval.

21. The financial position of the CBL has continued to improve. The CBL's 2007 budget target of a small surplus is a welcome development. However, given the CBL's already limited income, the staff stressed that these gains should be consolidated by controlling salaries, travel allowances, governors' fees, and other expenses. Specifically, the staff urged the adoption of travel guidelines consistent with those of the government (that were adopted in April 2006).

\section{Governance Issues}

22. The authorities approved an anticorruption policy paper in June 2006, paving the way for an independent anticorruption agency and other measures. The strategy is built on four main pillars comprising strengthening governance rules and procedures, reinforcing institutions, amending laws on corruption, and consultation with all sectors of society. They also ratified the $\mathrm{UN}$ and African Union Conventions against corruption and began implementing some measures to strengthen governance (paragraph 2 of the MEFP). The staff stressed the importance of finalizing, with donor assistance, Liberia's anticorruption strategy and policy matrix.

\section{Public Debt Issues}

23. Verification of the government's domestic debt obligations was delayed by the authorities' decision to employ external auditors to verify large obligations. The staff encouraged the authorities to complete the verification process to allow for a timely finalization of the government's domestic debt resolution strategy. They also stressed the importance for it to take account of the debt restructuring plans of the CBL and undercapitalized commercial banks, and to ensure that sufficient resources are available for 
its implementation. The authorities plan to discuss their proposed strategy with various creditors, and, subject to legislative approval, provide sufficient resources for its implementation.

\section{The authorities are eager to make faster progress in clearing Liberia's arrears to the Fund and receiving debt relief under the HIPC Initiative and MDRI-type relief. ${ }^{9}$} They emphasized their strong record under the current SMP and continued monthly repayments to the Fund. They intend to continue paying US\$60,000 a month to the Fund under the program for 2007. While the current level of payments to the IMF is not sufficient to stabilize its arrears, Liberia's status as a post-conflict country with significant reconstruction needs, limited external budget support, and very low international reserves, will make it difficult to increase payments beyond the current level. As noted by staff, that level would need to be discussed further if a RAP was being considered (under current RAP policy, such repayments must be sufficient to prevent a rise in arrears). The mission also noted the importance of a comprehensive approach to clear arrears to all multilateral institutions and to complete the reconciliation of Liberia's external debt to allow for the preparation of a debt sustainability analysis and preliminary HIPC document. The authorities noted that international financial advisors have been appointed to help reconcile external commercial debt. An experienced legal counsel is also being appointed in case creditors take legal action against the government.

\section{E. Relations with Donors}

\section{Liberia's reconstruction requires continued significant external financial and} technical support. Following the 2003 peace agreement, donor disbursements to Liberia have increased sharply to an estimated US\$300 million in 2006 (excluding the continued accumulation of arrears at about US\$140 million), and are tentatively projected to continue at a similar pace in $2007 .{ }^{10}$ These donor funds are spent almost entirely outside the government's budget and include significant TA. The staff and the authorities agreed that sustained progress with improving economic governance (including under the GEMAP), and further strengthening budget planning and implementation would facilitate a reallocation of donor support to the budget, as well as to mobilize additional assistance to address critical development needs. It will be important to assess the costs of the authorities' poverty reduction strategy to provide an estimate of resource needs over the medium term.

\footnotetext{
${ }^{9}$ Under current policies, Liberia's performance under the SMP cannot be counted as track record for the HIPC decision point.

${ }^{10}$ See Box 5, Country Report No. 06/166, May 8, 2006. Reliable data on donor funding outside the budget is not available. A key priority for the government is to strengthen the collection and reporting of data on aid flows.
} 


\section{F. Technical Assistance and Data Issues}

\section{Under the GEMAP framework, the deployment of international experts and} technical assistance have improved capacity at public institutions. Fund technical assistance has covered tax and customs administration, tax policy (including legislation), PFM, monetary policy operations, financial sector issues, and statistics. ${ }^{11}$ The authorities have been receptive to such assistance, and have already implemented a number of the recommendations. Capacity constraints, nevertheless, are significant, and continued support from Liberia's international partners is essential to the government's program for 2007.

\section{The lack of reliable and timely data impedes policy formulation and monitoring.}

The draft I-PRSP's goals to improve data production and dissemination (by, among other actions, strengthening the Liberia Institute for Statistics and Geo-Information Services) are thus welcome. The staff urged the authorities to finalize the medium-term national statistical plan and implement outstanding recommendations from the Fund's 1998 multisector statistics and 2003 assessment missions. ${ }^{12}$

\section{G. Program Monitoring and Risks}

\section{The authorities' letter of intent and their MEFP sets out their policies for the} SMP through year-end 2007. The program will be monitored against the quantitative and structural benchmarks in Tables 1 and 3 (Appendix I). The fiscal quantitative benchmarks for second-half 2007, derived from preliminary 2007/08 budget discussions, will be revised once the budget is final.

29. The ambitious program for $\mathbf{2 0 0 7}$ is subject to considerable risks. The government is committed to the program and have strong ownership of the planned reforms. However, the main risks to the program arise from significant capacity constraints at ministries and continued tension between the government and opposition-led legislature. The authorities' ability to achieve the ambitious objectives will depend on timely technical assistance and support from donors, and the president's ability to maintain an effective working relationship with the legislature.

\footnotetext{
${ }^{11}$ See Box 1 for details regarding the contribution from other donors to capacity building in public financial management and civil service reform. Donors are also providing support for the government's anticorruption policy, infrastructure reconstruction, reforms in the forestry and diamond sectors, and capacity building in judicial, law enforcement and security institutions.

${ }^{12}$ These include (i) establishment of a national business register; (ii) resumption of an annual Establishment Survey and National Accounts Questionnaire for manufacturing, mining, utilities and agriculture; and (iii) completion of a Household Income and Expenditure Survey.
} 


\section{Staff APpraisal}

30. Liberia, given its progress with economic reform in 2006, deserves continued strong support from the international community. The new government's endorsement of the GEMAP has been critical to supporting and monitoring economic governance and transparency improvements. The government, though it has faced severe capacity constraints and an opposition-led legislature, has (i) implemented a commitment control system, (ii) strengthened tax collection, (iii) comprehensively reviewed most contracts and concessions granted by the previous government, and (iv) improved CBL management.

\section{Despite overall progress under the SMP, some key goals required more time to}

be completed. Most quantitative benchmarks through end-September were achieved, but some of the ambitious structural reform measures were delayed. These include (i) completing the review of concessions and contracts, (ii) developing a strategy for resolving government's domestic debt obligations, and (iii) finalizing the government's anticorruption strategy. The staff welcomes the progress since September in achieving most of the outstanding benchmarks.

\section{A key challenge for Liberia is to establish a track record of effective budget}

implementation. The two-month delay in passing the 2006/07 budget disrupted expenditure approvals and led to the accumulation of arrears on government wages. While revenues have increased in 2006, expenditures through November have lagged, increasing government balances at the CBL. The slow spending partly reflects an inevitable learning curve, as the $\mathrm{BoB}$, line ministries and agencies, and the Ministry of Finance implement improved procurement and approval procedures. But a strong effort is now needed to further train line ministry procurement committees and speed up submission of purchase vouchers to the Ministry of Finance. Merging the BoB with the Ministry of Finance (an outstanding measure under the SMP) would also improve budget preparation and implementation. A strong track record of budget implementation would encourage donors to give more assistance, including in the form of budget support.

33. The authorities' program for $\mathbf{2 0 0 7}$ is appropriately ambitious and comprehensive. With the exception of continued accrual of external payments arrears, the staff considers that this ambitious program meets the standards of upper credit tranche conditionality. While the SMP is subject to considerable risks, the authorities deserve strong support from the international community, and looking ahead, the program for 2007 could provide a sound basis for quickly agreeing on a RAP, inter alia, once financing assurances for debt relief have been obtained. The program, which continues to have strong ownership from the government, builds on 2006 achievements, and would further improve economic governance, PFM, and tax and customs administration. Once the authorities finalize the anticorruption strategy, they will focus on establishing an anticorruption commission and implementing the domestic debt strategy. Going beyond the requirements of the SMP, the 
authorities also plan (i) a comprehensive civil service reform, and (ii) timely audits of several large ministries. Technical assistance will be critical to the program's success.

\section{The program continues to focus on maintaining low inflation by targeting a} broadly stable nominal exchange rate, while improving the health of the banking sector. Plans to restructure still undercapitalized banks and dissolve nonoperating and abandoned banks are important next steps. While the authorities would like to lift the moratorium on licensing new banks (a program commitment under the February-September 2006 SMP), the staff urged them to exercise extreme caution and to consult with the staff before considering the issuance of new licenses.

35. Under the 2007 program, the CBL will target a balanced budget. The chief administrator, who has binding co-signing authority, has been central to the CBL's improved performance in 2006. The CBL must now work to consolidate these gains and to appropriately control salaries, travel allowances, governors' fees, and other expenses. The authorities must also quickly finalize the 2006 audit of the CBL and agree on criteria to ensure annual auditing by an internationally reputable firm.

36. Liberia's external debt is unsustainable. The authorities should complete the reconciliation of Liberia's external debt to allow for the preparation of a debt sustainability analysis and preliminary HIPC document. Achieving the objectives of the SMP, including effective budget implementation, should help Liberia secure the international support it needs to resolve its large debt overhang. 
Figure 1. Liberia: Selected Economic Indicators, 2001-07
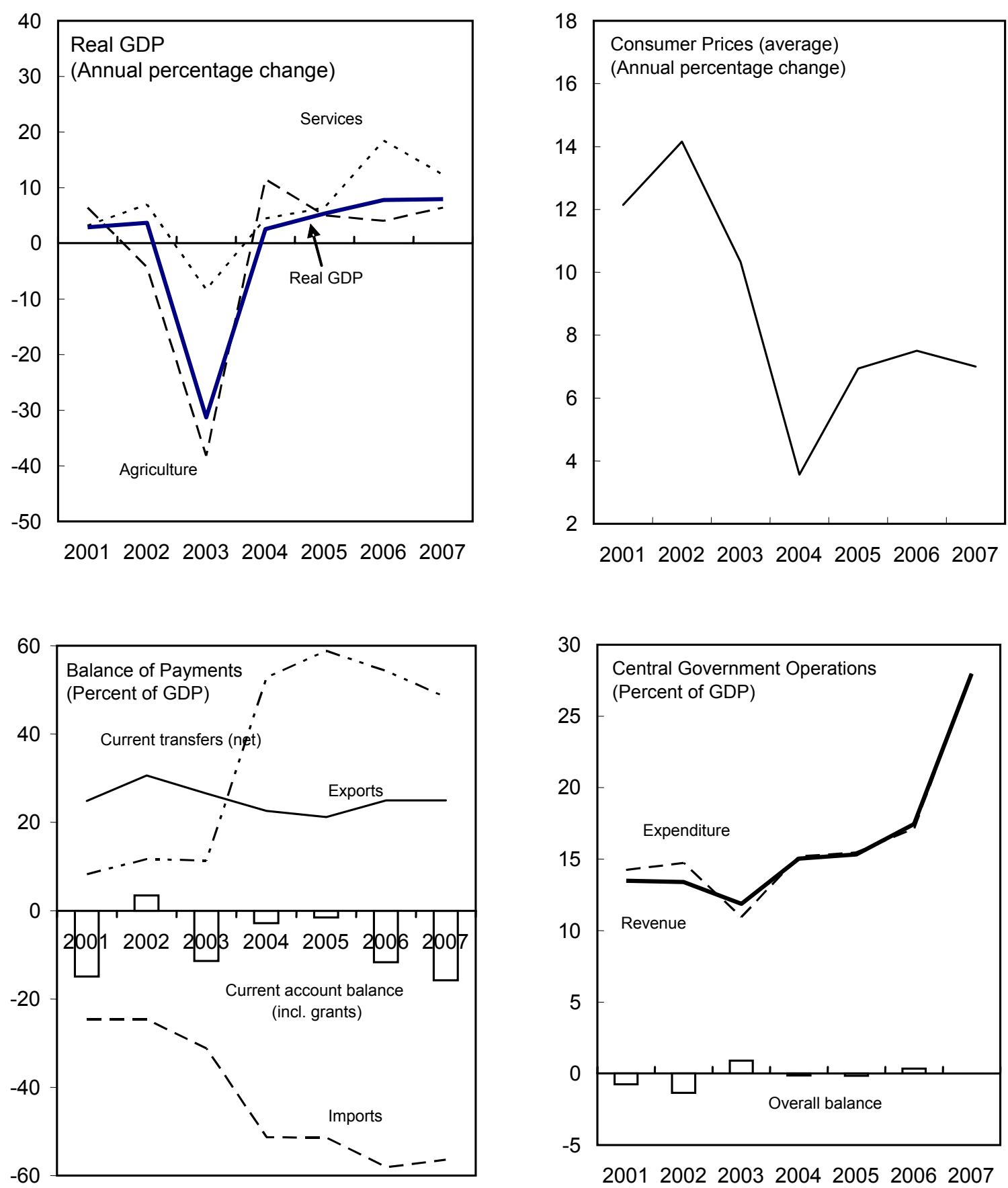

Sources: Liberian authorities; and Fund staff estimates and projections. 
Figure 1. Liberia: Selected Economic Indicators, 2001-07 (concluded)
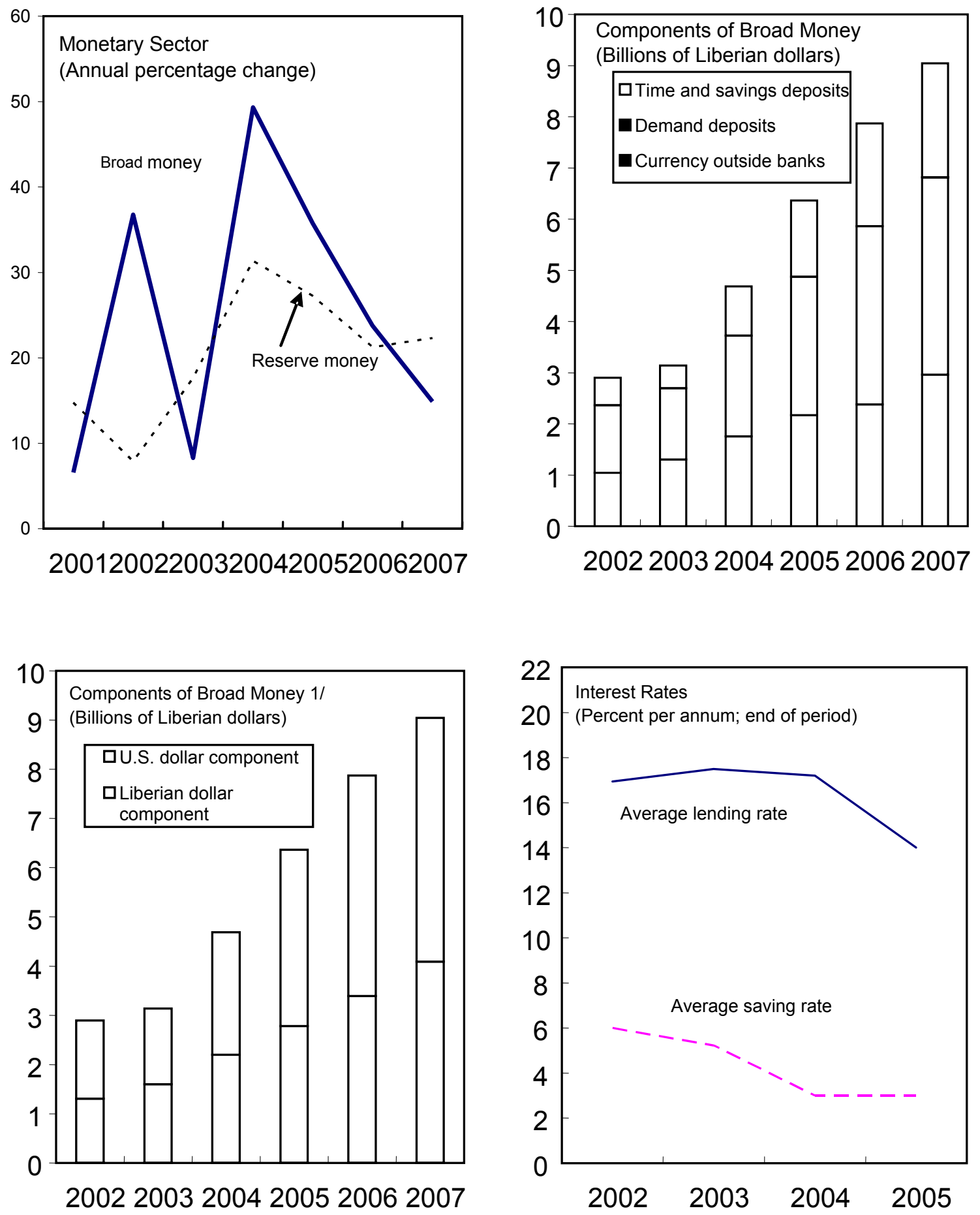

Sources: Liberian authorities; and Fund staff estimates and projections. 1/ Percent of total money supply. 
Figure 2. Liberia: Exchange Rate Developments, January 2000-November 2006
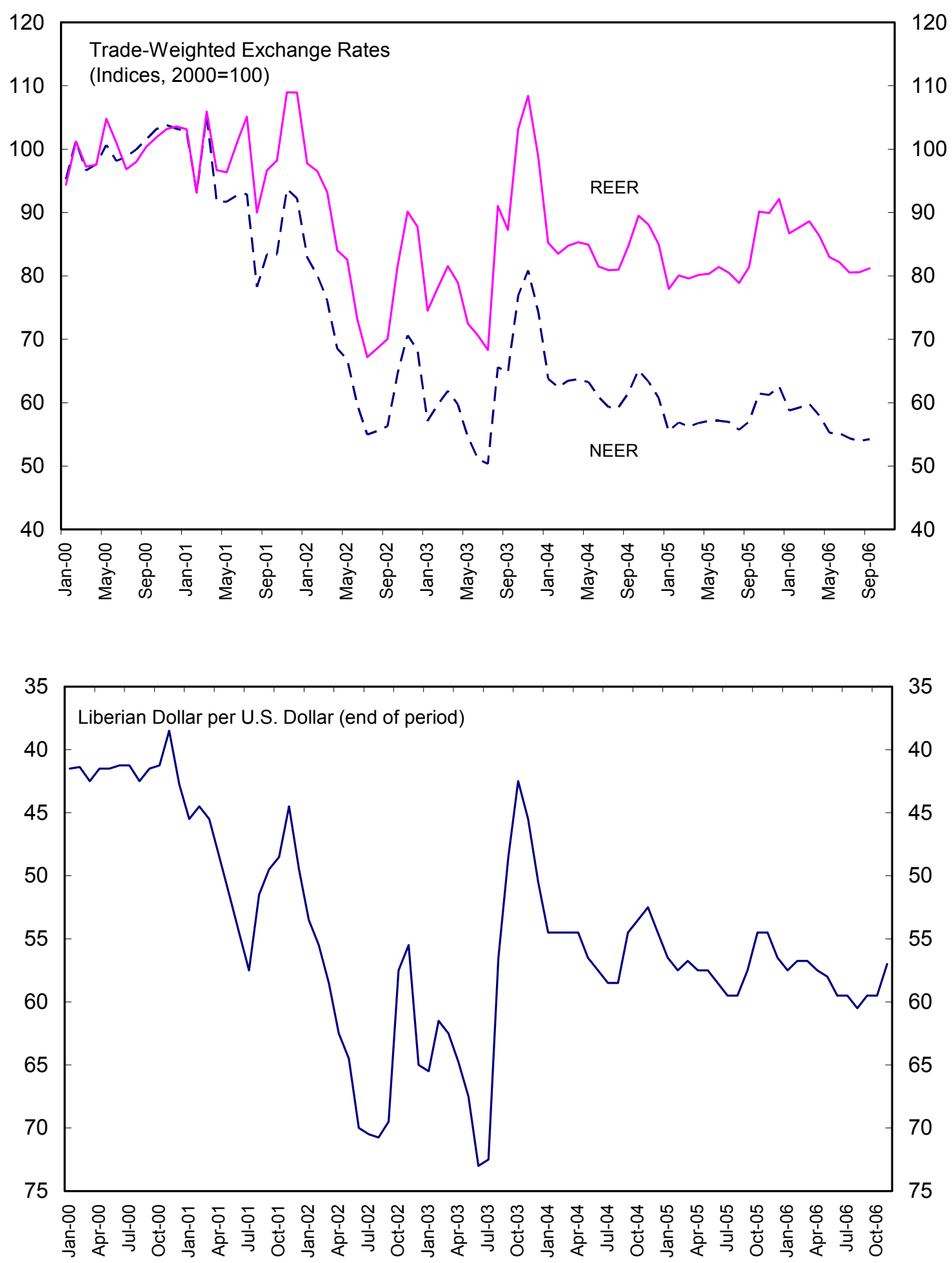

Sources: Liberian authorities; and Fund staff estimates and projections. 
Table 1. Liberia: Selected Economic and Financial Indicators, 2003-07

\begin{tabular}{|c|c|c|c|c|c|}
\hline & $\begin{array}{r}2003 \\
\text { Est. }\end{array}$ & $\begin{array}{r}2004 \\
\text { Est. }\end{array}$ & $\begin{array}{r}2005 \\
\text { Est. }\end{array}$ & $\begin{array}{l}2006 \\
\text { Proj. }\end{array}$ & $\begin{array}{l}2007 \\
\text { Proj. }\end{array}$ \\
\hline & \multicolumn{5}{|c|}{ (Annual percentage change, unless otherwise indicated) } \\
\hline \multicolumn{6}{|l|}{ National income and prices } \\
\hline Real GDP & -31.3 & 2.6 & 5.3 & 7.8 & 7.9 \\
\hline Consumer prices (annual average) ${ }^{1 /}$ & 10.3 & 3.6 & 6.9 & 7.5 & 7.0 \\
\hline Consumer prices (end of period) $)^{1 /}$ & 5.0 & 7.5 & 7.0 & 7.2 & 7.3 \\
\hline Nominal GDP (in millions of U.S. dollars) & 410.2 & 460.0 & 529.0 & 631.0 & 670.6 \\
\hline GDP deflator in U.S. dollars & 10.0 & 9.3 & 9.2 & 10.6 & -1.5 \\
\hline Real GDP per capita (in constant 1992 U.S. dollars) & 115.4 & 117.7 & 122.4 & 128.9 & 135.8 \\
\hline \multicolumn{6}{|l|}{ External sector (in U.S. dollar terms) } \\
\hline Exports of goods, f.o.b. & -34.5 & -4.7 & 8.1 & 40.4 & 6.2 \\
\hline Imports of goods, f.o.b. & -4.3 & 84.4 & 15.2 & 34.8 & 3.2 \\
\hline Terms of trade (deterioration - ) & 21.1 & 4.9 & 4.2 & 32.2 & -7.4 \\
\hline Official exchange rate ( $L \$ /$ US\$; end of period) & 50.5 & 54.5 & 56.5 & $\ldots$ & $\ldots$ \\
\hline Nominal effective exchange rate (end of period) & 9.1 & -18.4 & 3.1 & $\ldots$ & $\ldots$ \\
\hline Real effective exchange rate (end of period) & 12.7 & -14.1 & 8.4 & $\ldots$ & $\ldots$ \\
\hline \multicolumn{6}{|l|}{ Central government operations } \\
\hline Total revenue and grants & -33.1 & 42.0 & 17.2 & 35.8 & 48.0 \\
\hline Of which : tax revenue & -37.2 & 49.1 & 13.1 & 35.1 & 27.2 \\
\hline Total expenditure and net lending & -43.8 & 55.3 & 17.2 & 31.8 & 51.1 \\
\hline Of which : current expenditure & -5.6 & 144.7 & 19.9 & 27.9 & 29.5 \\
\hline capital expenditure & -62.2 & -51.9 & 1.0 & 60.1 & 175.9 \\
\hline \multicolumn{6}{|c|}{$\begin{array}{l}\text { (Annual percentage change; beginning-period stock of money, } \\
\text { unless otherwise indicated) }\end{array}$} \\
\hline \multicolumn{6}{|l|}{ Money and banking } \\
\hline Net foreign assets & 223.6 & -456.0 & -96.6 & -29.2 & -25.8 \\
\hline Net domestic assets & -215.3 & 505.3 & 132.4 & 53.0 & 40.8 \\
\hline Net claims on government & -320.1 & 533.5 & 133.4 & 52.3 & 44.4 \\
\hline Claims on nongovernment & -8.1 & 21.1 & 7.2 & 6.0 & 4.2 \\
\hline Other items net & 112.9 & -49.4 & -8.3 & -5.4 & -7.7 \\
\hline Broad money (M2) ${ }^{2 /}$ & 8.3 & 49.3 & 35.7 & 23.7 & 15.0 \\
\hline Velocity (GDP relative to broad money) & 6.6 & 5.3 & 4.7 & 4.7 & 4.5 \\
\hline Reserve money & 17.6 & 31.4 & 27.2 & 21.2 & 22.6 \\
\hline Broad money (stocks, in billions of Liberian dollars) & 3.1 & 4.7 & 6.4 & 7.9 & 9.1 \\
\hline Liberian dollar component & 1.6 & 2.2 & 2.8 & 3.4 & 4.1 \\
\hline \multirow[t]{2}{*}{ U.S. dollar component } & 1.5 & 2.5 & 3.6 & 4.5 & 5.0 \\
\hline & \multicolumn{5}{|c|}{ (In percent of GDP) } \\
\hline \multicolumn{6}{|l|}{ Central government operations (January-December) } \\
\hline Total revenue and grants & 11.9 & 15.0 & 15.3 & 17.5 & 24.3 \\
\hline Of which : total revenue & 11.1 & 14.8 & 14.6 & 16.5 & 19.7 \\
\hline Total expenditure and net lending & 11.0 & 15.2 & 15.5 & 17.1 & 24.3 \\
\hline Of which : current expenditure & 6.0 & 13.0 & 13.6 & 14.6 & 17.8 \\
\hline capital expenditure & 5.0 & 2.1 & 1.9 & 2.5 & 6.5 \\
\hline Overall fiscal balance (cash basis) & 0.9 & -0.1 & -0.1 & 0.4 & 0.0 \\
\hline \multicolumn{6}{|l|}{ External sector } \\
\hline Current account balance, including grants (deficit, -) & -11.4 & -2.8 & -1.6 & -11.7 & -15.7 \\
\hline Of which: public interest payments due & -11.6 & -11.7 & -15.6 & -16.3 & -16.6 \\
\hline Current account balance, excluding grants (deficit, -) & -16.2 & -44.0 & -55.8 & -59.6 & -60.4 \\
\hline Trade balance (deficit, -) & -4.6 & -28.7 & -30.2 & -33.1 & -31.4 \\
\hline Exports, f.o.b. & 26.6 & 22.6 & 21.2 & 25.0 & 25.0 \\
\hline Imports, f.o.b. & -31.2 & -51.3 & -51.4 & -58.1 & -56.4 \\
\hline \multirow[t]{2}{*}{ Public sector external debt outstanding (total) } & 820.0 & 812.0 & 691.8 & 596.4 & 577.9 \\
\hline & \multicolumn{5}{|c|}{ (In millions of U.S. dollars, unless otherwise indicated) } \\
\hline Current account balance including grants (deficit, -) & -46.8 & -13.1 & -8.3 & -73.7 & -105.6 \\
\hline Trade balance (deficit, -) & -19.0 & -132.2 & -159.7 & -208.8 & -210.7 \\
\hline CBL's net foreign exchange position & -1.3 & 3.3 & 6.5 & 19.9 & 31.6 \\
\hline (in months of imports of goods and services) & -0.1 & 0.1 & 0.2 & 0.5 & 0.8 \\
\hline
\end{tabular}

Sources: Liberian authorities; and Fund staff estimates and projections.

1/ Technical adjustments were made to the CPI in 2004 in light of the substitution of some items in the CPI survey in mid-2004 2/ Defined as Liberian currrency outside banks plus demand, time, and savings deposits in Liberian and U.S. dollars. 
Table 2. Liberia: Balance of Payments, 2003-07

\begin{tabular}{|c|c|c|c|c|c|}
\hline & $\begin{array}{r}2003 \\
\text { Est. }\end{array}$ & $\begin{array}{r}2004 \\
\text { Est. }\end{array}$ & $\begin{array}{r}2005 \\
\text { Est. }\end{array}$ & $\begin{array}{r}2006 \\
\text { Est. }\end{array}$ & $\begin{array}{l}2007 \\
\text { Proj. }\end{array}$ \\
\hline & \multicolumn{5}{|c|}{ (Millions of U.S. dollars, unless otherwise indicated) } \\
\hline Trade balance & -19 & -132 & -160 & -209 & -211 \\
\hline Exports, f.o.b. & 109 & 104 & 112 & 158 & 167 \\
\hline Of which: rubber & 44 & 93 & 99 & 141 & 126 \\
\hline timber & 55 & 0 & 0 & 0 & 15 \\
\hline Imports, f.o.b & -128 & -236 & -272 & -366 & -378 \\
\hline Petroleum & -30 & -66 & -89 & -125 & -138 \\
\hline Rice & -39 & -34 & -30 & -62 & -34 \\
\hline Donor + FDI related & -19 & -106 & -141 & -167 & -184 \\
\hline Other & -52 & -30 & -13 & -12 & -22 \\
\hline Services (net) & -14 & -37 & -47 & -70 & -72 \\
\hline Income (net) & -60 & -87 & -113 & -137 & -147 \\
\hline Of which: public interest payments due & -47 & -54 & -82 & -103 & -111 \\
\hline Current transfers (net) & 47 & 243 & 311 & 342 & 324 \\
\hline Donor transfers (net) ${ }^{1 /}$ & 20 & 189 & 287 & 302 & 300 \\
\hline Private transfers (net) & 27 & 53 & 24 & 40 & 24 \\
\hline Current account balance & -47 & -13 & -8 & -74 & -106 \\
\hline Current account balance, excluding grants & -66 & -202 & -295 & -376 & -405 \\
\hline Capital and financial account & -28 & -39 & -43 & -51 & -30 \\
\hline Official financing & -28 & -30 & -36 & -36 & -36 \\
\hline Disbursements & 0 & 0 & 0 & 0 & 0 \\
\hline Amortization & -28 & -30 & -36 & -36 & -36 \\
\hline Private financing & 0 & -9 & -7 & -15 & 6 \\
\hline Direct foreign investment & 0 & 0 & 3 & 6 & 11 \\
\hline Other investment (incl. trade credit) & 0 & -9 & -10 & -21 & -5 \\
\hline Errors and omissions & -1 & -27 & -64 & -1 & 0 \\
\hline Overall balance & -75 & -79 & -115 & -126 & -136 \\
\hline Financing & 75 & 79 & 115 & 126 & 136 \\
\hline Change in official reserves (increase -) & 0 & -5 & -3 & -13 & -12 \\
\hline Arrears (accrual +$)^{2 /}$ & 75 & 84 & 118 & 139 & 147 \\
\hline Use of Fund credit (net change in arrears) & 8 & 10 & 17 & 17 & 17 \\
\hline Increase in non-Fund arrears & 67 & 74 & 101 & 122 & 130 \\
\hline \multicolumn{6}{|l|}{ Memorandum items: } \\
\hline \multicolumn{6}{|l|}{ Current account balance (percent of GDP): } \\
\hline Including grants & -11.4 & -2.8 & -1.6 & -11.7 & -15.7 \\
\hline Excluding grants & -16.2 & -44.0 & -55.8 & -59.6 & -60.4 \\
\hline Excluding grants and public interest payments due & -4.6 & -32.2 & -40.2 & -43.3 & -43.8 \\
\hline Trade balance (percent of GDP) & -4.6 & -28.7 & -30.2 & -33.1 & -31.4 \\
\hline \multicolumn{6}{|l|}{ Public sector external debt (medium and long term) } \\
\hline Debt outstanding, including arrears & 3,364 & 3,735 & 3,660 & 3,763 & 3,876 \\
\hline (percent of exports of goods and services) & 2,420 & 2,742 & 2,538 & 1,965 & 1,904 \\
\hline (percent of GDP) & 820 & 812 & 692 & 596 & 578 \\
\hline Debt service charges & 74.9 & 83.9 & 118.4 & 139.0 & 147.4 \\
\hline (percent of GDP) & 18.3 & 18.3 & 22.4 & 22.0 & 22.0 \\
\hline Terms of trade $(1997=100)$ & 130.2 & 136.7 & 142.5 & 188.4 & 174.4 \\
\hline CBL's net foreign exchange position & -1 & 3 & 7 & 20 & 31 \\
\hline CBL's net foreign exchange position (months of imports of goods and services) & -0.1 & 0.1 & 0.2 & 0.5 & 0.8 \\
\hline CBL's net foreign exchange position (months of non-donor imports) & -0.1 & 0.2 & 0.4 & 0.8 & 1.2 \\
\hline GDP at current prices & 410 & 460 & 529 & 631 & 671 \\
\hline
\end{tabular}

Sources: Liberian authorities; and Fund staff estimates and projections.

1/ A steady rise is assumed for donor inflows at about half the rate of nominal GDP growth, based on Liberia's extensive reconstruction needs and assumed strong donor support. Donor inflows during the first few years from 2007 are expected to be affected by the projected reduction in UNMIL operations.

2/ Apart from token payments to international financial institutions, Liberia is not servicing is external debt. 
Table 3. Liberia: Summary of Central Government Operations, 2002/03-2006/07

\begin{tabular}{|c|c|c|c|c|c|}
\hline & $2002 / 03$ & $2003 / 04$ & $2004 / 05$ & $2005 / 06$ & $2006 / 07$ \\
\hline & \multicolumn{5}{|c|}{ (Millions of U.S. dollars) } \\
\hline Total revenue and grants ${ }^{1 /}$ & 56.6 & 59.0 & 80.3 & 89.6 & 135.1 \\
\hline Total revenue & 56.6 & 56.0 & 79.3 & 84.6 & 120.9 \\
\hline Tax revenue & 48.5 & 55.3 & 75.7 & 81.0 & 116.8 \\
\hline Taxes on international trade and transactions & 23.9 & 24.3 & 30.2 & 35.3 & 56.4 \\
\hline Taxes on income & 9.4 & 9.4 & 28.4 & 25.1 & 33.7 \\
\hline Taxes on goods and services & 14.8 & 21.3 & 16.9 & 20.3 & 21.2 \\
\hline Of which: maritime revenues & 11.0 & 15.5 & 10.1 & 12.1 & 11.0 \\
\hline Other & 0.4 & 0.3 & 0.3 & 0.3 & 5.5 \\
\hline Of which: overdue tax collection & 0.0 & 0.0 & 0.0 & 0.0 & 4.8 \\
\hline Nontax revenue & 8.1 & 0.8 & 3.6 & 3.6 & 4.1 \\
\hline Of which: stumpage fees and land rental & 7.3 & 0.1 & 0.0 & 0.0 & 0.0 \\
\hline Of which: income and transfer from SOEs & 0.0 & 0.0 & 0.0 & 0.0 & 0.8 \\
\hline Grants & 0.0 & 3.0 & 1.0 & 5.0 & 14.2 \\
\hline Budget support & 0.0 & 3.0 & 1.0 & 1.0 & 0.0 \\
\hline Project $^{2 /}$ & 0.0 & 0.0 & 0.0 & 4.0 & 14.2 \\
\hline Total expenditure and net lending (cash basis) ${ }^{1 /}$ & 69.2 & 50.6 & 77.0 & 72.2 & 152.5 \\
\hline Current expenditure & 28.3 & 46.9 & 66.3 & 64.5 & 119.1 \\
\hline Wages and salaries & 13.1 & 24.3 & 42.3 & 30.7 & 48.5 \\
\hline Goods and services & 5.9 & 15.8 & 16.0 & 15.4 & 46.8 \\
\hline Interest on debt & 8.8 & 2.8 & 2.0 & 2.4 & 2.2 \\
\hline External & 0.5 & 0.2 & 0.7 & 1.1 & 1.2 \\
\hline Domestic $^{3 /}$ & 8.3 & 2.6 & 1.4 & 1.4 & 1.0 \\
\hline Domestic arrears clearance/payments & 0.0 & 0.0 & 0.0 & 6.2 & 5.3 \\
\hline Subsidies, transfers, and net lending & 0.6 & 4.0 & 6.0 & 9.8 & 16.4 \\
\hline Capital expenditure & 40.9 & 3.7 & 10.6 & 7.7 & 33.4 \\
\hline Internally financed & 40.9 & 3.7 & 10.6 & 3.7 & 19.2 \\
\hline Externally financed ${ }^{2 /}$ & 0.0 & 0.0 & 0.0 & 4.0 & 14.2 \\
\hline Statistical discrepancies & 0.0 & 0.0 & 0.0 & 0.0 & 0.0 \\
\hline Overall surplus or deficit (cash basis) & -12.6 & 8.4 & 3.4 & 17.4 & -17.4 \\
\hline adjustment to cash basis ${ }^{4 /}$ & na & na & na & 17.4 & -17.4 \\
\hline \multirow[t]{2}{*}{ Overall surplus or deficit (commitment basis) } & na & na & na & 0.0 & 0.0 \\
\hline & \multicolumn{5}{|c|}{ (Percent of GDP, unless otherwise indicated) } \\
\hline Total revenue and grants & 11.9 & 13.6 & 16.2 & 15.4 & 20.8 \\
\hline Total revenue & 11.9 & 12.9 & 16.0 & 14.6 & 18.6 \\
\hline Grants & 0.0 & 0.7 & 0.2 & 0.9 & 2.2 \\
\hline Total expenditure and net lending & 14.5 & 11.6 & 15.6 & 12.4 & 23.4 \\
\hline Current expenditure & 5.9 & 10.8 & 13.4 & 11.1 & 18.3 \\
\hline Of which: wages and salaries ${ }^{5 /}$ & 2.7 & 5.6 & 8.6 & 5.3 & 7.4 \\
\hline Capital expenditure & 8.6 & 0.9 & 2.1 & 1.3 & 5.1 \\
\hline Overall surplus or deficit (incl. grants) & -2.6 & 1.9 & 0.7 & 3.0 & -2.7 \\
\hline Grants & 0.0 & 0.7 & 0.2 & 0.9 & 2.2 \\
\hline Overall surplus or deficit (excl. grants) & -2.6 & 1.2 & 0.5 & 2.1 & -4.9 \\
\hline
\end{tabular}

Sources: Liberian authorities; and Fund staff estimates and projections.

$1 / 2006 / 07$ revenue projections are GOL estimates for the budget. 2006/07 expenditure projections include $\$ 17.4$ million of commitments at end-2005/06 projected to be recorded as expenditures in 2006/07.

2/ Includes initial disbursements under a WB pre-arrears clearance grant ( $\$ 30$ million), AfDB ISP grant ( $\$ 4.5$ million) and a grant from France (\$1.3 million). Some of the projects funded by these grants are managed through the MDB -supported Project Financial

Management Unit at the MoF and are implemented with assistance from ministries. The increase in 2006/07 reflects greater government involvement in implementation of donor funded projects.

3/ Prior to 2006, interest payments on domestic debt and banking fees had been reported as interest payments.

4/ Adjustments in 2005/06 and 2006/07 are a result of commitments at end-2005/06 projected to be recorded as expenditures in 2006/07. 5/ For 2005/06 and 2006/07, when reported on a commitment basis, values are $6.0 \%$ and $6.8 \%$, respectively. 
Table 4. Liberia: Monetary Survey, 2002-07

\begin{tabular}{|c|c|c|c|c|c|}
\hline & $\begin{array}{l}2003 \\
\text { Dec. }\end{array}$ & $\begin{array}{l}2004 \\
\text { Dec. }\end{array}$ & $\begin{array}{l}2005 \\
\text { Dec. }\end{array}$ & $\begin{array}{l}2006 \\
\text { Dec. } \\
\text { Proj. }\end{array}$ & $\begin{array}{l}2007 \\
\text { Dec. } \\
\text { Proj. }\end{array}$ \\
\hline & \multicolumn{5}{|c|}{ (Millions of Liberian dollars, unless otherwise indicated) } \\
\hline Net foreign assets & $-30,335$ & $-44,646$ & $-49,175$ & $-51,034$ & $-53,068$ \\
\hline Of which: Fund credit and overdue charges & $-30,579$ & $-45,998$ & $-51,422$ & $-53,478$ & $-55,618$ \\
\hline Of which: CBL's gross foreign reserves & 370 & 1,019 & 1,432 & 2,396 & 3,245 \\
\hline assets corresponding to Government U.S. dollar denominated deposits at CBL & 304 & 107 & 70 & 0 & 0 \\
\hline assets corresponding to commercial banks' U.S. dollar deposits at CBL & 131 & 730 & 993 & 1,242 & 1,375 \\
\hline CBL's net foreign exchange position & -64 & 183 & 370 & 1,154 & 1,870 \\
\hline Net domestic assets & 33,473 & 49,333 & 55,537 & 58,907 & 62,122 \\
\hline Net domestic credit & 45,594 & 63,003 & 69,593 & 73,307 & 77,131 \\
\hline Net claims on government & 43,597 & 60,343 & 66,594 & 69,923 & 73,420 \\
\hline Of which: Fund credit and overdue charges & 30,579 & 45,998 & 51,422 & 53,478 & 55,618 \\
\hline Claims on private sector & 1,136 & 1,651 & 2,064 & 3,064 & 3,391 \\
\hline Claims on public enterprises & 59 & 106 & 83 & 210 & 210 \\
\hline Claims on nonbank financial institutions & 86 & 187 & 110 & 110 & 110 \\
\hline Claims on non-government & 1,997 & 2,660 & 2,999 & 3,384 & 3,711 \\
\hline Other items, net & $-12,120$ & $-13,669$ & $-14,056$ & $-14,400$ & $-15,009$ \\
\hline \multicolumn{6}{|l|}{ Monetary aggregates } \\
\hline Currency outside banks (Liberian banknotes and coins only) & 1,304 & 1,755 & 2,169 & 2,378 & 2,972 \\
\hline Commercial banks' reserves at Central Bank of Liberia $1 /$ & 152 & 142 & 230 & 522 & 578 \\
\hline Of which: required reserves & 132 & 111 & 155 & 224 & 247 \\
\hline Reserve Money (billions of Liberian dollars) $2 /$ & 1,561 & 2,050 & 2,609 & 3,163 & 3,879 \\
\hline Commercial bank deposits $3 /$ & 1,835 & 2,932 & 4,193 & 5,495 & 6,082 \\
\hline Total demand deposits & 1,391 & 1,972 & 2,702 & 3,482 & 3,854 \\
\hline Liberian dollar denominated deposits & 137 & 184 & 221 & 366 & 405 \\
\hline U.S. dollar denominated deposits & 1,254 & 1,788 & 2,481 & 3,116 & 3,449 \\
\hline Time, savings, and other deposits & 444 & 960 & 1,491 & 2,013 & 2,227 \\
\hline Liberian dollar denominated deposits & 160 & 260 & 392 & 650 & 720 \\
\hline U.S. dollar denominated deposits & 284 & 700 & 1,099 & 1,362 & 1,508 \\
\hline Broad money (M2) 4/ & 3,139 & 4,687 & 6,362 & 7,873 & 9,054 \\
\hline Liberian dollar component & 1,601 & 2,199 & 2,781 & 3,394 & 4,097 \\
\hline U.S. dollar component & 1,538 & 2,488 & 3,581 & 4,479 & 4,957 \\
\hline \multicolumn{6}{|l|}{ Memorandum items: } \\
\hline U.S. dollar component broad money (excluding banknotes, millions of U.S. dollars) & 30.5 & 45.7 & 63.4 & 76.3 & 81.1 \\
\hline U.S. dollar component of broad money (percent of broad money, excluding banknotes) & 49.0 & 53.1 & 56.3 & 56.9 & 54.7 \\
\hline U.S. dollar denominated demand deposits (millions of U.S. dollars) & 24.8 & 32.8 & 43.9 & 53.1 & 56.4 \\
\hline U.S. dollar denominated time, saving, and other deposits (millions of U.S. dollars) & 5.6 & 12.8 & 19.5 & 23.2 & 24.7 \\
\hline Broad money (annual change) & 8.3 & 49.3 & 35.7 & 23.7 & 15.0 \\
\hline Liberian dollar component broad money (percent of beginning period broad money) & 10.1 & 19.0 & 12.4 & 9.6 & 8.9 \\
\hline U.S. dollar component broad money (percent of beginning period broad money) & -1.8 & 30.3 & 23.3 & 14.1 & 6.1 \\
\hline CBL's net foreign exchange position (millions of U.S. dollars) & -1.3 & 3.3 & 6.5 & 19.9 & 31.6 \\
\hline Money Multiplier & 2.0 & 2.3 & 2.4 & 2.5 & 2.3 \\
\hline Velocity (GDP relative to broad money) & 6.6 & 5.3 & 4.7 & 4.7 & 4.5 \\
\hline Currency/deposits (in percent; Liberian dollars only) & 554 & 395 & 354 & 234 & 264 \\
\hline Nominal GDP (millions of Liberian dollars; annualized basis) & 20,717 & 25,069 & 29,891 & 37,041 & 40,998 \\
\hline
\end{tabular}

Sources: Liberian authorities; and Fund staff estimates.

1/ Derived from commercial banks' balance sheets (Liberian dollar denominated)

2/ Liberian dollar currency outside banks and commercial banks reserves (Liberian dollar denominated) held at central bank.

3/ One bank has been excluded from the deposit since May 2003

4/ Excluding U.S. dollars in circulation 
Table 5. Liberia: Core Set of Financial Soundness Indicators, 2003-06 (Percent, unless otherwise indicated)

\begin{tabular}{|c|c|c|c|c|}
\hline & $\begin{array}{r}2003 \\
\text { Dec } \\
\end{array}$ & $\begin{array}{r}2004 \\
\mathrm{Dec} \\
\end{array}$ & $\begin{array}{r}2005 \\
\text { Dec } \\
\end{array}$ & $\begin{array}{r}2006 \\
\text { Mar }\end{array}$ \\
\hline Number of banks & 3 & 3 & 5 & 5 \\
\hline \multicolumn{5}{|l|}{ Capital adequacy } \\
\hline Regulatory capital to risk-weighted assets $1 /$ & -2.0 & -4.4 & 2.3 & 2.2 \\
\hline \multicolumn{5}{|l|}{ Asset quality } \\
\hline Nonperforming loans to total loans & 62.0 & 23.8 & 15.5 & 18.3 \\
\hline Loan loss provisions to nonperforming loans & 94.0 & 79.0 & 97.0 & 73.9 \\
\hline Loan concentration & 100.0 & 100.0 & 100.0 & 100.0 \\
\hline Agriculture & 9.2 & 8.0 & 10.6 & 9.5 \\
\hline Mining and Quarrying & 0.0 & 0.0 & 0.1 & 0.0 \\
\hline Manufacturing & 0.4 & 0.7 & 0.5 & 0.5 \\
\hline Construction & 2.6 & 2.3 & 2.7 & 2.8 \\
\hline Transportation, Storage, and Communication & 0.2 & 1.8 & 4.4 & 3.7 \\
\hline Trade, Hotels and Restaurants & 10.0 & 19.1 & 13.5 & 16.0 \\
\hline Others & 77.7 & 68.0 & 68.1 & 67.5 \\
\hline Government of Liberia & 28.4 & 25.6 & 27.2 & 23.6 \\
\hline Central Bank of Liberia & 30.7 & 27.7 & 26.8 & 25.8 \\
\hline \multicolumn{5}{|l|}{ Earnings and profitability } \\
\hline Return on assets & -24.0 & -3.0 & 0.5 & 0.7 \\
\hline Return on equity & -32.5 & -32.6 & 3.2 & 4.4 \\
\hline Noninterest income to total income & 81.0 & 84.8 & 81.4 & 78.3 \\
\hline Net interest margin & 2.0 & 1.4 & 1.8 & 0.6 \\
\hline \multicolumn{5}{|l|}{ Liquidity } \\
\hline Liquid assets to net assets & 51.0 & 40.0 & 17.8 & 13.6 \\
\hline
\end{tabular}

Source: Central Bank of Liberia.

1/ Adjusted by the CBL. 


\section{Liberia. Appendix I - Letter of Intent}

Monrovia, January 18, 2007

Mr. Rodrigo de Rato

Managing Director

International Monetary Fund

Washington, D.C. 20431

USA

Dear Mr. de Rato:

Steadfast implementation of economic reforms since the government took office in early 2006, including a strengthening of the public financial management and the monetary policy framework, has supported an improvement in macroeconomic outcomes. Projections for 2007 suggest continued strong growth and single-digit inflation. In this context, we appreciate the IMF's recognition of our efforts through the lifting of the declaration of noncooperation and the initiation of de-escalation of remedial measures against Liberia in October of last year. We also appreciate the extensive technical assistance provided by the IMF.

The government remains committed to further strengthening public institutions and policies to ensure macroeconomic stability and improved governance in order to reverse the economic decline inflicted on Liberia during the recent civil conflicts. Key to these efforts are further strengthening public financial management and the financial sector, and implementing the recently approved anticorruption strategy. Our policy framework for 2007 will be guided by the interim Poverty Reduction Strategy Paper that we are now finalizing.

We view performance under the 2006 staff-monitored program (SMP) as evidence that we are now in a position to implement an upper credit tranche program in order to establish the necessary track record for debt relief under the HIPC Initiative and MDRI-type relief. While we understand that financing assurances for debt relief, which are necessary for approval of a rights accumulation program (RAP), are not yet in place, we hope that the government's program for 2007 set out in the attached Memorandum of Economic and Financial Policies (MEFP) (Attachment I) can form the basis for the Board's approval to convert the Staff-Monitored Program into a RAP once such assurances have been obtained. We also trust that Fund Management and Board will agree to consider performance under our entire 2007 program - rather than only from the date of its transformation into a RAP - as part of the track record required for the HIPC Decision Point.

The policies and measures set forth in the attached MEFP reflect the understandings reached with the IMF staff during the November 2006 SMP review mission, which we believe can achieve the objectives of the program. We will, however, take any additional 
measures that may become necessary for this purpose. We will remain in close consultation with IMF staff on the adoption of such measures, and in advance of any revisions to the policies contained in the MEFP. The government will provide the IMF staff with all information it requests to assess implementation of the SMP. A Technical Memorandum of Understanding defining indicative targets of the SMP and the data to be reported is also attached (Attachment II).

Sincerely yours,

$/ \mathrm{s} /$

Antoinette M. Sayeh

Minister of Finance /s/

Joseph Mills Jones

Governor of the CBL

Attachments: Memorandum on Economic and Financial Policies

Technical Memorandum of Understanding 


\section{Attachment I - Memorandum of Economic and Financial Policies}

\section{INTRODUCTION}

1. After taking office on January 16, 2006, the government of President Ellen JohnsonSirleaf quickly took a number of actions to strengthen the performance of the Liberian economy. The government endorsed the Governance and Economic Management Assistance Program (GEMAP) that was agreed in September 2005 between the National Transitional Government of Liberia (NTGL) and key international donors. ${ }^{13}$ Under this framework, international experts were deployed to key revenue-generating agencies, the Central Bank of Liberia (CBL), the Ministry of Finance, the Ministry of Lands, Mines and Energy, and the Bureau of the Budget (BoB). With support from donors, the government strengthened public expenditure management through an interim commitment control system, established the Public Procurement and Concessions Commission, and a framework for reviewing all contracts and concessions that originated under the NTGL. The government introduced a number of steps to address widespread corruption: it adopted revised guidelines on foreign travel by government officials consistent with the recommendations of an ECOWASsponsored audit, and approved an anticorruption policy that, inter alia, provides for the establishment of an independent anticorruption agency.

2. Good progress was made in achieving the ambitious objectives set under the government's 150-Day Action Plan for the first five months of its tenure (FebruaryJune 2006), including substantially strengthening public revenues and expenditure management; the lifting of UN timber sanctions; emergency repairs to important national roads; restoration of water and electricity provision to parts of Monrovia; and launching the Truth and Reconciliation Commission. The government also adopted a zero tolerance policy on corruption, commenced an exercise to eliminate ghost workers in the civil service, drafted a Civil Service Code of Conduct, and required all serving Cabinet members to publicly declare their assets and liabilities.

3. The government quickly requested support from the IMF to design a sustainable macroeconomic policy framework, and to monitor implementation of policies within this framework, inter alia, to begin building a track record of policy implementation that would be required for the eventual clearance of Liberia's arrears to the IMF and seeking debt relief under the HIPC Initiative and MDRI-type relief. The government successfully achieved the key objectives under the staff-monitored program (SMP) during 2006. It met with one

\footnotetext{
${ }^{13}$ The GEMAP consists of six components, namely: (i) strengthening financial management and accountability; (ii) improving budgeting and expenditure management; (iii) improving procurement practices and granting of concessions; (iv) establishing effective processes to control corruption; (v) supporting key institutions; and (vi) supporting capacity building.
} 
exception, all the SMP's quantitative benchmarks through end-September (Table 1). ${ }^{14}$ However, progress toward achieving all the structural benchmarks under the program was limited by even more serious capacity constraints than had originally been anticipated, a challenging working relationship with the legislature, and delays in deploying the international experts required under the GEMAP. Key achievements include: (i) implementing the commitment control system; (ii) strengthening the Large Taxpayers Unit (LTU); (iii) developing a strategy to deal with overdue tax obligations; (iv) strengthening monetary policy implementation by resuming regular bi-weekly foreign exchange auctions; and (v) finalizing a framework for reviewing contracts and concessions granted under the NTGL. Significant progress has been made in meeting the outstanding benchmarks, including: (i) completing the review of contracts and concessions; (ii) verifying the stock of domestic debt, and developing a domestic debt resolution strategy consistent with a debt restructuring plan for the CBL; (iii) approving an anticorruption strategy; (iv) submitting a status report on GEMAP implementation, endorsed by the Economic and Governance Steering Committee (EGSC); and (v) posting the financial statements of key state-owned enterprises on the Ministry of Finance's website.

\section{Current Economic Situation}

4. Despite the promising start, the economic challenges facing the government are monumental. Socio-economic indicators in Liberia are amongst the worst in the world: real GDP per capita declined by about 80 percent during 1987-2003, unemployment is estimated at about 85 percent, around three-quarters of the population lives on less than US\$1 per day, and approximately 90 percent of the population is considered to be food insecure. Liberia's population also suffers from high incidence of diseases such as tuberculosis, cholera, malaria and yellow fever, and high under-5 and maternal mortality rates. Liberia furthermore suffers from significant deficiencies in both physical and human capital; almost two decades of civil war severely damaged infrastructure, including electricity generation, transportation (roads, railways, airports and seaports), telecommunications, water supply and sanitation. It also slowed human capital formation and caused an exodus of skilled workers.

5. Economic activity benefited from the cessation of conflict in 2003 and large-scale external support. Supported by a recovery in rubber production, reconstruction activities, and the contribution of a large donor presence to the services sector, real GDP growth is estimated to have risen gradually from $2 \frac{1}{2}$ percent in 2004 to $5 \frac{1}{2}$ percent in 2005 , after having declined by over 30 percent in 2003 . Although rubber production in the first nine months of 2006 declined more rapidly than earlier projected on account of occasional incidents of violence on the plantations, the recovery in construction activity has been

\footnotetext{
${ }^{14}$ The continuous quantitative benchmark on the nonaccumulation of domestic arrears could not be met in July and August 2006 as civil service wages could not be paid in the absence of an approved budget for fiscal year 2006/07. These payments were made in September after legislative approval of the budget in late-August.
} 
stronger than previously projected. Real GDP growth in 2006 is estimated to have increased to around 8 percent. While the lifting of the UN timber sanctions did not have a significant impact on real output growth in 2006, the timber industry is expected to make a significant contribution to growth and government revenues in the medium-term.

6. Price and exchange rate volatility have subsided since 2004, benefiting from the reestablishment of peace, and a strengthening of the CBL's monetary policy framework. ${ }^{15}$ The exchange rate of the Liberian dollar to the U.S. dollar remained broadly stable during the first 11 months of 2006, depreciating by 0.9 percent from a level of L\$56.5/US\$1 at endDecember 2005. The year-on-year growth in broad money fluctuated in a range between 3040 percent, while growth in Liberian dollar broad money (in percent of beginning-period broad money) slowed to 9.5 percent in October from 13.5 percent in January $2006 .{ }^{16}$ Inflation, benefiting from the easing of supply constraints and relative exchange rate stability, remained in single-digits throughout 2005 and the first 10 months of 2006. Year-on-year inflation was 5.9 percent in October 2006, compared with 7 percent in December 2005.

7. The CBL took a number of steps in 2006 to strengthen the monetary policy framework and the financial sector. It established a strengthened Money Management and Policy Review Committee, with primary responsibility for guiding monetary policy decision making, as well as a regular program of bi-weekly foreign exchange auctions. While the size of the auctions, at times, has been limited by the availability of foreign exchange and reserve accumulation targets under the SMP, it has broadly achieved its objectives. Progress was also made with efforts to strengthen weak domestic banks. Memoranda of understanding (MOU's) were finalized for restructuring two undercapitalized banks, resident supervisors were placed in these banks, and a moratorium was placed on the licensing of new banks during the SMP. Significant progress was also made in improving the financial position of the CBL. Internal management and financial systems and controls were strengthened, and the CBL achieved a smaller budget deficit than originally projected.

8. In a sharp break with the past, fiscal management improved significantly during the first year of the government's term in office as a number of actions were taken to increase revenue and strengthen public expenditure management. On the revenue side, these include better enforcement of preshipment inspections for imports, strengthening tax collection, and eliminating noncash payment of taxes. Mainly reflecting these measures, actual revenue

\footnotetext{
${ }^{15}$ This framework recognizes that in a highly dollarized and open economy, the exchange rate is the key variable through which monetary imbalances affect prices. Against this background, the CBL uses the exchange rate as an indicator of domestic monetary conditions, and gears its management of Liberian dollar liquidity to maintaining broad stability in the exchange rate.

${ }^{16}$ Broad money includes all deposit liabilities of commercial banks denominated in U.S. dollars and Liberian dollars and currency outside banks in Liberian dollars. While the amount of U.S. dollar currency is likely to be large in the highly dollarized and cash-based economy, the CBL has no means to measure it.
} 
collection, excluding grants, rose by 82 percent in the first five months of fiscal year 2006/07 (compared with the same period in 2005/06). The level of revenue at end-November was consistent with the government's target for 2006/07. On the expenditure side, the government introduced, with donor support, a commitment control system to ensure that allotments to line ministries were in line with available revenues. While no new expenditure requests were approved in July and August due to a delay in legislative approval of the 2006/07 budget, line ministries were able to operate on the basis of expenditure approvals in late May and June, although salary and wage payments were delayed. Spending picked up in September to December 2006, but delays in expenditure processing by line ministries remain a concern.

9. External developments have been characterized by a substantial widening of the trade deficit since 2004, mostly on account of strong growth in donor-funded imports. While exports also increased, they remained well below the pre-war levels on account of the UN ban on timber and diamond exports. In this environment, little progress was made in restoring net official reserves, which rose by only US\$8 million from 2003 to 2005. However, reserves rose more substantially by US\$13 million in 2006, to a level covering about half of monthly imports. Liberia's external debt has been in arrears for more than two decades, and is unsustainable; at end-2005, the ratio of debt to exports was estimated at about 2,000 percent, while the ratio of debt to GDP amounted to almost 600 percent.

\section{The Government's ECONOMiC Program: 2007}

10. The program for 2007 is based on the draft Interim Poverty Reduction Strategy Paper (I-PRSP) for the period July 2006-June 2008. The draft I-PRSP is centered on the consolidation of peace and stability, and positioning Liberia for sustained poverty-reducing economic growth and development, and is based on four pillars, namely enhancing security, revitalizing economic growth, strengthening governance and the rule of law, and rehabilitating infrastructure and basic service delivery.

11. The government's development strategy confirms the private sector's role as the main engine for growth. To this end, the economic policy framework aims at providing an enabling environment for private sector development, including maintaining macroeconomic stability, strengthening economic governance, and addressing impediments to private sector development. The government's program for 2007 will build on progress made during the first year of its administration.

12. For 2007, the government is projecting growth in real GDP at 7-8 percent, about the same as that estimated for 2006, while annual inflation is targeted to remain at around 7 percent. Despite a worsening terms of trade in 2007, the trade balance, relative to GDP, is projected at about the same level as in 2006 as rice imports are expected to return to the historical average, and exports are expected to be boosted by the resumption of timber exports. 


\section{A. Fiscal Policy}

13. The government's fiscal policy in 2007 will be formulated within the constraint of maintaining a cash-based balanced budget. The government recognizes that unsustainable public debt levels exclude the possibility for a more active fiscal policy stance, and that it will have to pursue balanced budgets for some time to come. It is nevertheless expected that continuing progress in strengthening fiscal transparency and governance will allow donors to increasingly channel grant aid through the budget to help meet unfunded I-PRSP goals as substantial additional resources are required to address critical reconstruction needs. The government will continue to focus on policies to broaden the tax base and further strengthen revenue administration, and to improve public expenditure management, with an increased emphasis on poverty-reducing expenditures.

14. To this end, the government developed an ambitious budget for fiscal year 2006/07, with total public revenues, including contingent revenues, targeted to rise by 52 percent. While the government is confident that this target will be achieved, line ministries have developed prioritized monthly cash plans to identify areas where expenditure can be cut should the need arise.

15. The government has implemented a number of measures to support its revenue target for 2006/07, including: (i) increasing the penalty for not undertaking pre-shipment inspection to ensure larger coverage, including at Roberts International Airport and some rural ports of entry; (ii) reducing import tax exemptions and improving management of those granted to NGOs and others to limit abuse; (iii) redefining the base for the goods and services tax on imports in line with the provisions of the Liberia Revenue Code; and (iv) increasing the excise tax on beer and cigarettes, and eliminating the differentiation between imported and domestic products in the application of excise taxes. With assistance from the IMF, the government also has reviewed the Liberia Revenue Code and regulations and will take steps to rationalize existing exemptions and adopt an administrative procedure law to establish a transparent process for the issuance of new regulations. A plan to reform the investment incentive code has been developed, inter alia, to eliminate the granting to individual investors of ad hoc tax exemptions outside the Liberia Revenue Code.

16. Efforts will continue to strengthen tax and customs administration. Important measures in this regard include: (i) strengthening enforcement of tax collection, including collection of overdue taxes (ii) continuing efforts to strengthen the LTU; and (iii) reducing tax exemptions further as a result of the review of contracts and concessions granted under the previous government. The government will also implement recommendations from ongoing IMF TA to strengthen revenue administration, including effectively employing the revised Tax Identification Number, and commencing with organizational changes based on taxpayer segmentation. These reforms should increase the efficiency of revenue administration and help widen the tax base through better coordination between tax collection, auditing and enforcement. While revenues from customs have increased sharply 
in the first six months of the fiscal year, continued efforts to strengthen customs administration will lead to further increases. In this regard, with assistance from the European Commission, the government is considering the possible outsourcing of customs administration.

17. In the area of expenditure management, the government will continue to strengthen the interim commitment control system to ensure that public expenditure is consistent with actual monthly revenue, and follows the prioritized cash plans. While the system ensures that transactions with the government are well documented and adhere to the new Public Procurement and Concessions Act, further efforts will be undertaken to accelerate the pace of expenditures, including by providing further training on the process to the procurement committees within individual line ministries. While the 2006/07 budget has started the process of refocusing public expenditure toward critical poverty-reducing areas, the government will continue its efforts to direct more resources to health, education, infrastructure and rural development. To this end, the government will seek to create fiscal space by continuing to remove ghost workers from the public payroll, and initiating a comprehensive civil service reform program, including the reform of civil service compensation.

18. The government will further strengthen budget planning and reporting. In this regard, legislation has been submitted to the legislature to integrate the $\mathrm{BoB}$ and the Bureau of Maritime Affairs into the Ministry of Finance. The Ministry of Finance and the BoB have developed a budget calendar for fiscal year 2007/08 to ensure timely submission of the budget for legislative approval. The government has also taken initial steps to develop a multi-year fiscal framework to guide line ministries in expenditure planning. Initial steps have been taken to implement the GFSM 2001 framework to improve the reporting of fiscal data and facilitate macro fiscal policy analysis. To further improve transparency, the 2006/07 budget and first quarter fiscal report have been posted on the Finance Ministry's website, and publication of monthly revenue outturns has begun. Publication of monthly expenditure outturns will commence shortly.

19. To regularize relations with domestic creditors and strengthen the CBL and commercial banks, the government will commence implementation of the domestic debt resolution strategy. To this end, it will discuss its strategy with the different categories of creditors, and issue instruments consistent with it. Subject to legislative approval, the government will provide sufficient resources for implementation of the strategy.

\section{B. Monetary and Exchange Rate Policy}

20. The primary objective of monetary policy is the maintenance of price stability. Given that the scope for monetary policy in the current dollarized environment is limited, and recognizing that the exchange rate represents the main transmission mechanism through which monetary imbalances affect prices, the CBL will continue to use the exchange rate as 
the main indicator of domestic monetary conditions. The CBL will therefore gear its management of Liberian dollar liquidity to maintaining broad stability in the exchange rate. To strengthen its ability to conduct monetary policy in this environment, the CBL will: (i) begin using the revised liquidity framework; (ii) improve the reserve requirement system; (iii) revise the foreign exchange auction rules, and introduce procedures for purchase auctions; and (iv) broaden the collection of data on foreign exchange volumes traded in the foreign exchange market and the flow of remittances.

21. The CBL is currently targeting its net liquid foreign exchange position to reach a minimum of US\$31.6 million by end-December 2007 (Table 1). However, the accumulation of foreign reserves will be consistent with the objective of maintaining broad exchange rate stability.

22. The Liberian economy continues to operate under a dual currency arrangement. However, the pursuit of credible macroeconomic policies, development of Liberia's financial system, and improving the health of the banking sector, together with ongoing efforts to strengthen governance and secure peace and stability, will in due course allow for a marketdriven de-dollarization of the economy.

23. Looking forward, the CBL will continue refining its operational framework for monetary policy. In this regard, it will establish the rules and procedures for the introduction of credit and deposit auctions which could be used to manage liquidity on a short-term basis, as well as the preferred strategy for the development of money and interbank markets and the introduction of monetary instruments.

24. The CBL will continue with ongoing efforts to strengthen domestic banks. In this connection, steps will be taken to ensure that restructuring and recapitalization plans developed for banks will be implemented. Accordingly, a Compliance Committee has been established that will, among others, monitor the implementation of the MOU's agreed with the banks. Meanwhile, the CBL intends to strengthen its capacity to undertake timely and effective supervision of domestic banks, an exercise for which external technical assistance will be needed. In this context, the CBL will remain very guarded in granting licenses for new banks. However, consideration may be given to licensing internationally reputable banks from outside Liberia that have the capacity to start operations with a strong capital base, and have a credible plan for contributing to the revitalization and growth of the Liberian economy. The CBL has commenced the process of bringing to final resolution non-operating and abandoned banks. The legal counsel has prepared documentation to submit individual cases to the courts for final resolution, which has been endorsed by the Board of Governors.

25. Building on the progress made in 2006 to strengthen its financial position, the CBL Board of Governors has approved a balanced budget for 2007. In this connection, the CBL will adopt travel guidelines consistent with those of the government (that was adopted in April 2006, and that are currently under review). In agreement with the IMF, the external 
audit of the 2005 accounts of the CBL, a structural benchmark under the 2006 SMP, has been rescheduled to focus on preparing the 2006 accounts. This audit is expected to be completed by end-March 2007. Following the recommendations of the safeguards assessment requested by the CBL in September 2006, the CBL has formally adopted the International Financial Reporting Standards (IFRS) as its accounting framework, the transition to be completed by 2008. The CBL will also adopt, with TA, a formal training program on central bank accounting and IFRS; and establish clear criteria for selection and rotation of external auditors with a view to ensure the selection of a reputable firm to audit the CBL's financial statements pursuant to the International Standards of Accounting (ISA).

\section{Strengthening Governance}

26. The government accords high priority to strengthening governance and the rule of law since weaknesses in these areas contributed significantly to Liberia's recent history of civil war. The government's program in this area is multi-faceted, and includes combating corruption, strengthening the judiciary and police, and building capacity and transparency in public institutions.

27. In the area of combating corruption, notable progress has been made in a relatively short period of time, including the ratification of the UN and AU anticorruption conventions, adoption of an anticorruption strategy by the government, and establishment of a Civil Service Code of Conduct. During 2007, the government's focus will be on commencing implementation, with donor assistance, of its anticorruption strategy. An important element of this strategy will be establishing an independent anticorruption agency by endSeptember 2007, as provided for in the government's anticorruption strategy.

28. Under the GEMAP, progress has been made in strengthening capacity and enhancing transparency in public institutions through the deployment of international experts, technical assistance to ministries and agencies, and the posting of government reports on the internet and in the local media. In the year ahead, the government will continue with international support to strengthen capacity for policy formulation and implementation, further improve public sector management, and develop adequate economic and social data bases.

29. The lack of reliable and timely data is an important impediment to the government's ability to formulate policies and monitor their implementation. In this regard, it has been receiving extensive support from donors. A key challenge in the year ahead (in the context of preparatory work for the full PRSP) will be to formulate a national strategy for the development of the statistical system, and to strengthen the capacity of the Liberian Institute for Statistics and Geo-Information Services. 


\section{Other Reforms}

30. To support private sector development, the government will begin addressing the impediments identified in the World Bank's recent FIAS analysis of the investment climate, including: (i) the large informal sector; (ii) energy supply; (iii) access to finance; (iv) land ownership and tenure; (v) tax policy; (vi) the investment code; and (vii) administrative and regulatory issues. Recognizing the importance of agriculture, forestry, and mining as potential sources of growth, the government will finalize policy frameworks to guide development in these sectors. Building on progress to date, the government will implement the reforms required to achieve the removal of sanctions on diamond exports. To further reintegrate Liberia into the world economy and promote economic efficiency, the government will initiate a comprehensive tariff reform aimed at adopting the ECOWAS common external tariff.

31. While some progress has been made in repairing some roads and providing electricity and water services to selected parts of Monrovia, a major challenge will be rebuilding Liberia's infrastructure that was nearly destroyed during the civil wars. The government's aim in the short run is to restore basic services to facilitate economic activity and combat poverty. While the government will work closely with the international community, it will also seek to secure private sector participation in view of the substantial investment required. Access to education and health facilities will also be improved.

\section{RELATIONS WITH THE IMF AND OTHER INTERNATIONAL DONORS}

32. The government will continue to make progress toward normalizing relations with the

international community with a view to the eventual resolution of Liberia's debt overhang. It will therefore continue to make monthly payments of US\$60,000 to the IMF, US\$25,000 to the World Bank, and US\$15,000 to the African Development Bank. While the government recognizes that the current level of payments to the IMF is not sufficient to stabilize its arrears, Liberia's status as a post-conflict country with significant reconstruction needs, limited external budget support, and very low international reserves, will make it difficult to increase payments beyond the current level.

33. Achieving rapid progress toward clearing Liberia's arrears to the international financial institutions and receiving comprehensive debt relief from its international creditors are critical steps in securing the progress that has been made thus far, and in supporting the government's reconstruction efforts. The government has been consulting extensively with official creditors, and has also started reconciling debt records to prepare for the preliminary debt sustainability analysis that is required under the HIPC Initiative. The government continues to plead for flexibility and creativity in addressing Liberia's arrears to the multilateral institutions. With bilateral assistance, the government appointed international financial advisors to assist with the reconciliation of private sector external debt, and is 
appointing a highly experienced legal counsel to assist the government in the event of legal action from these creditors.

34. Implementation of the program for 2007 will be monitored on the basis of the quantitative benchmarks described in Table 1. The structural benchmarks, which build on progress under the 2006 SMP, are described in Table 3. 


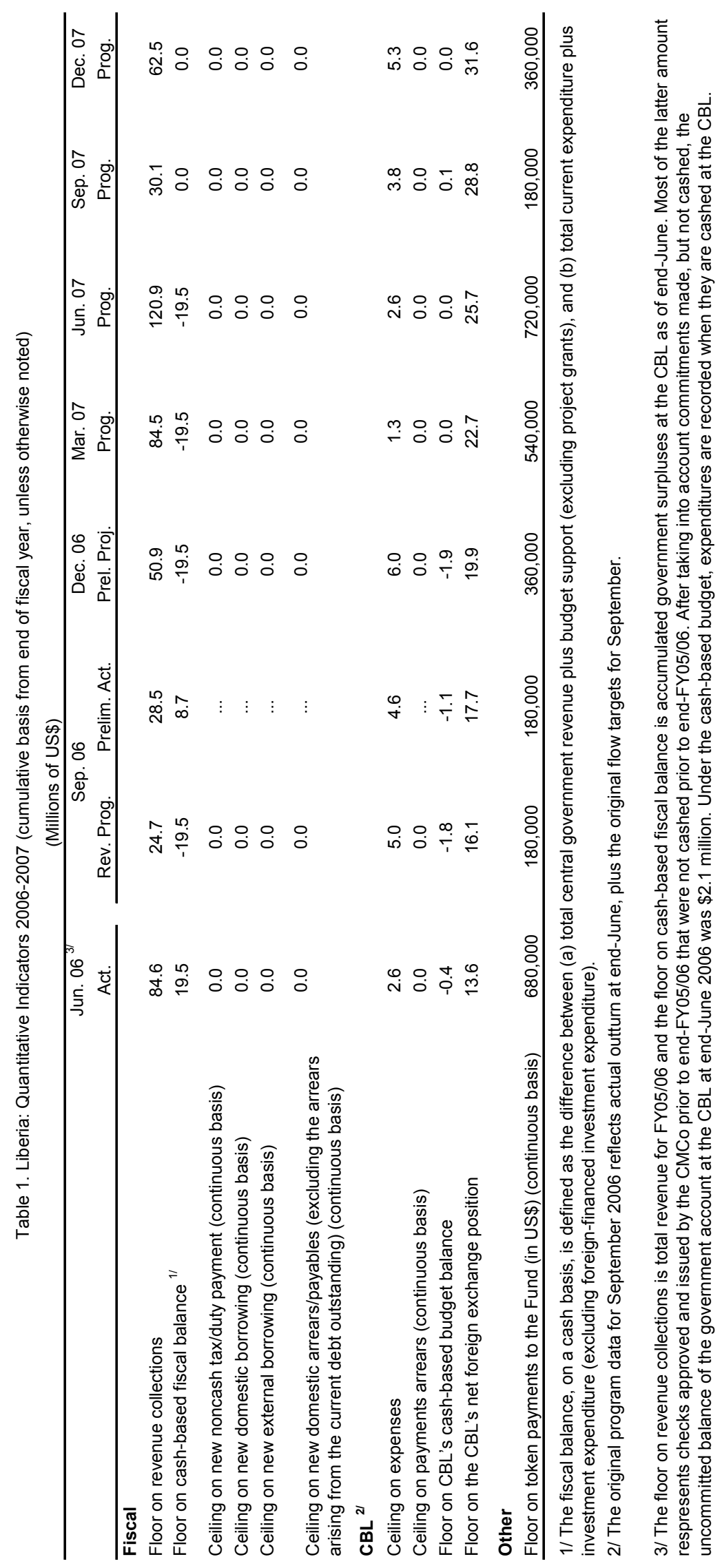


Table 2. SMP for February-September 2006-Structural Benchmarks

\begin{tabular}{|c|c|c|}
\hline Measures & Target dates & Status \\
\hline \multicolumn{3}{|l|}{ Fiscal Management } \\
\hline Strengthen the Large Taxpayer Unit (LTU) & End-March 2006 & Implemented by end-March \\
\hline $\begin{array}{l}\text { - Create a large taxpayer audit unit inside the } \\
\text { LTU with reallocation of staff within MoF }\end{array}$ & & \\
\hline $\begin{array}{l}\text { - Introduce a monthly information exchange to } \\
\text { the LTU from BIVAC }\end{array}$ & & \\
\hline $\begin{array}{l}\text { Increase the number of large taxpayers from } 60 \text { to } \\
110 \text { by auditing hidden taxpayers and/or lowering } \\
\text { the threshold value }\end{array}$ & End-June 2006 & Implemented by end-July \\
\hline $\begin{array}{l}\text { Develop a timetable to ensure approval of the } \\
2006 / 07 \text { budget }\end{array}$ & End-March 2006 & Implemented by end-March \\
\hline $\begin{array}{l}\text { Submit budget for legislative approval prior to } \\
\text { commencement of fiscal year }\end{array}$ & End-June 2006 & Implemented by end-June \\
\hline $\begin{array}{l}\text { Develop a strategy to deal with overdue tax } \\
\text { obligations }\end{array}$ & End-June 2006 & Implemented by end-July \\
\hline $\begin{array}{l}\text { Implement an interim commitment control system in } \\
\text { accordance with FAD TA recommendations: }\end{array}$ & $\begin{array}{l}\text { Continuous from } \\
\text { end-June } 2006\end{array}$ & Implemented from end-June \\
\hline $\begin{array}{l}\text { - The Bureau of the Budget to only allocate to } \\
\text { line ministries in line with monthly cash plans }\end{array}$ & & \\
\hline $\begin{array}{l}\text { - The line ministries to ensure that their } \\
\text { commitments do not exceed allotments }\end{array}$ & & \\
\hline $\begin{array}{l}\text { - The MoF to issue a public announcement that } \\
\text { only purchase orders with the Bureau of General } \\
\text { Accounting's special seal would be valid }\end{array}$ & & \\
\hline $\begin{array}{l}\text { Integrate the Bureau of the Budget and the Bureau of } \\
\text { Maritime Affairs into the Ministry of Finance }\end{array}$ & End-June 2006 & $\begin{array}{l}\text { Ongoing - legislation expected to be } \\
\text { considered during } 2007 \text { legislative } \\
\text { session }\end{array}$ \\
\hline $\begin{array}{l}\text { Establish the stock of domestic debt of the GOL, and } \\
\text { complete the verification process }\end{array}$ & End-June 2006 & Implemented by end-December \\
\hline $\begin{array}{l}\text { Finalize the domestic debt resolution strategy, } \\
\text { consistent with a restructuring plan for the CBL }\end{array}$ & $\begin{array}{l}\text { End-September } \\
2006\end{array}$ & $\begin{array}{l}\text { Ongoing - draft strategy completed by } \\
\text { end-December }\end{array}$ \\
\hline CBL operations & & \\
\hline $\begin{array}{l}\text { Revise the terms of reference for the money } \\
\text { management committee to reflect the new } \\
\text { responsibility of monetary policy, and ensure the } \\
\text { committee operates in accordance with its ToR }\end{array}$ & $\begin{array}{l}\text { Continuous from } \\
\text { end-March } 2006\end{array}$ & Implemented from end-March \\
\hline $\begin{array}{l}\text { Publicize the final Monetary Policy Framework } \\
\text { paper on the CBL website }\end{array}$ & End-March 2006 & Implemented by end-March \\
\hline $\begin{array}{l}\text { Formulate a financial restructuring plan for CBL in } \\
\text { collaboration with GOL, supported by IMF TA } \\
\text { experts }\end{array}$ & $\begin{array}{l}\text { End-September } \\
2006\end{array}$ & Implemented by end-December \\
\hline $\begin{array}{l}\text { Hold regular weekly or biweekly foreign exchange } \\
\text { auctions }\end{array}$ & $\begin{array}{l}\text { Continuous from } \\
\text { end-March } 2006\end{array}$ & Implemented from end-March \\
\hline
\end{tabular}


Table 2. SMP for February-September 2006-Structural Benchmarks (cont.)

\begin{tabular}{|c|c|c|}
\hline Measures & Target dates & Status \\
\hline $\begin{array}{l}\text { Conduct an external audit of the CBL by auditors of } \\
\text { international reputation }\end{array}$ & $\begin{array}{l}\text { End-September } \\
2006\end{array}$ & $\begin{array}{l}\text { Ongoing - target date was postponed to } \\
\text { end-April } 2007 \text { to allow audit of } 2006 \\
\text { accounts }\end{array}$ \\
\hline \multicolumn{3}{|l|}{ Governance and other issues } \\
\hline $\begin{array}{l}\text { Finalize the program for prioritizing and reviewing } \\
\text { all concessions, contracts, and licenses granted } \\
\text { under NTGL, and identify associated revenue flows, } \\
\text { with assistance provided by international partners }\end{array}$ & End-April 2006 & Implemented by end-April \\
\hline $\begin{array}{l}\text { Complete review of concessions, contracts, and } \\
\text { licenses granted under the NTGL, with assistance } \\
\text { provided by international partners }\end{array}$ & $\begin{array}{l}\text { End-September } \\
2006\end{array}$ & Implemented by end-December \\
\hline $\begin{array}{l}\text { Implement recommendations of audit of travel } \\
\text { expenses, including revision of policy on travel } \\
\text { allowances }\end{array}$ & $\begin{array}{l}\text { Continuous } \\
\text { from end-March } \\
2006\end{array}$ & Implemented from end-March \\
\hline $\begin{array}{l}\text { Develop a national anti-corruption strategy for the } \\
\text { GOL, including a policy matrix for implementation, } \\
\text { with assistance provided by international partners }\end{array}$ & End-May 2006 & Implemented by end-December \\
\hline $\begin{array}{l}\text { Post on MoF's website complete financial } \\
\text { statements of revenue-generating agencies (National } \\
\text { Ports Authority, Roberts International Airport, } \\
\text { Liberian Petroleum Refining Corporation, Forestry } \\
\text { Development Authority, and Bureau of Maritime } \\
\text { Affairs), endorsed by financial controllers }\end{array}$ & $\begin{array}{l}\text { End-September } \\
2006\end{array}$ & Implemented by end-December \\
\hline $\begin{array}{l}\text { Submit a status report, endorsed by the Economic } \\
\text { Governance Steering Committee, on implementation } \\
\text { of the Governance and Economic Management } \\
\text { Assistance Program }\end{array}$ & $\begin{array}{l}\text { End-September } \\
2006\end{array}$ & Implemented by end-December \\
\hline
\end{tabular}


Table 3. Structural Benchmarks for 2007 SMP

\begin{tabular}{|c|c|}
\hline Measures & Target dates \\
\hline \multicolumn{2}{|l|}{ Fiscal policy } \\
\hline $\begin{array}{l}\text { Commence implementation of the domestic debt resolution strategy, and } \\
\text { develop a plan for settlement of cross-debts between the government and state- } \\
\text { owned enterprises }\end{array}$ & End-March 2007 \\
\hline Submit a balanced cash-based budget for $2007 / 08$ for legislative approval & End-May 2007 \\
\hline $\begin{array}{l}\text { Develop and implement a comprehensive plan to reform the investment } \\
\text { incentive code and submit legislation to repeal Section 204(e) of the Liberia } \\
\text { Revenue Code of 2000, as well as the } 2004 \text { Act amending it, which allow the } \\
\text { government to enter into ad hoc tax concession agreements with individual } \\
\text { investors }\end{array}$ & End-June 2007 \\
\hline Reorganize administration of domestic taxes by taxpayer segmentation & End-June 2007 \\
\hline \multicolumn{2}{|l|}{ Financial sector } \\
\hline $\begin{array}{l}\text { Establish clear audit selection and rotation procedures and criteria for the CBL } \\
\text { to select an internationally reputable audit firm to conduct the CBL's future } \\
\text { external audits, pursuant to ISA, beginning in financial year } 2007\end{array}$ & End-March 2007 \\
\hline $\begin{array}{l}\text { Appoint an auditor, consistent with the criteria above, to audit the CBL's } \\
\text { financial accounts for } 2007\end{array}$ & End-September 2007 \\
\hline $\begin{array}{l}\text { Develop a restructuring plan for the remaining undercapitalized banks } \\
\text { consistent with the CBL's Bank Reconstruction and Resolution Policy }\end{array}$ & End-June 2007 \\
\hline \multicolumn{2}{|l|}{ Other Areas } \\
\hline $\begin{array}{l}\text { Establish an independent anticorruption agency, including submission of the } \\
\text { required legislation for legislative approval, consistent with the } \\
\text { government's anticorruption strategy }\end{array}$ & End-September 2007 \\
\hline $\begin{array}{l}\text { Submit for legislative enactment an administrative procedure law that } \\
\text { establishes a transparent process for the issuance of regulations pursuant to the } \\
\text { Liberia Revenue Code of } 2000 \text {, and submit legislation to repeal other laws and } \\
\text { revoke regulations that are inconsistent with the law }\end{array}$ & End-September 2007 \\
\hline Replace the Monrovia CPI with the Harmonized CPI & End-February 2007 \\
\hline
\end{tabular}




\section{Attachment II - Technical Memorandum of Understanding (TMU) for the Staff- Monitored Program for 2007}

1. This memorandum sets out the understandings between the Liberian authorities and the International Monetary Fund (IMF) regarding the definitions of the quantitative and structural performance criteria and benchmarks for the program for 2007, as well as the reporting requirements. The definitions are valid at the start of the program but may need to be revisited during the program reviews to ensure that the memorandum continues to reflect the best understanding of the Liberian authorities and the IMF staff in monitoring the program.

\section{Quantitative Performance CRITERIA AND BENCHMARKS}

\section{A. Test Dates}

2. Quantitative performance benchmarks have been set for end-March, end-June, endSeptember, and end-December 2007.

\section{B. Definitions and Computation}

3. For the purposes of the program, the Government is defined as the central Government of Liberia (GoL). This definition excludes legally autonomous state-owned enterprises whose budgets are not included in the central government budget. The operations of the central government will be presented in US dollars with all revenues and expenditures that are denominated in Liberian dollars converted at the end of period exchange rate.

4. Government revenue includes all tax and nontax receipts transferred into the US dollar GoL accounts at the Central Bank of Liberia (CBL), including income and transfers from state-owned enterprises and public institutions (excluding external loans and grants). The GoL accounts at the CBL include the GoL General Account No. 2, the GoL Special Rice Fund, and the Timber Revenue Account and the Liberian dollar account at the CBL comprising the GoL General Account. For the purposes of the program, the revenues of the GoL are measured on the basis of cash balances posted in the four accounts specified above converted to US dollars using the end of period exchange rate.

5. The cash-based fiscal balance is defined as the difference between (a) government revenue defined in paragraph 4 of this TMU (including budget support grants, but excluding earmarked external loans and grants); and (b) government current expenditure plus capital expenditure (excluding foreign-financed expenditure for earmarked purposes). For the purposes of measurement, the monthly cash-based balanced outturn will be measured by the net change in the balances of GoL accounts held at the CBL (including budget support grants, but excluding earmarked loans and grants and expenditures funded by these loans and grants). GoL accounts at the CBL shall be defined as comprising the US dollar GoL General Account No. 2, the GoL Special Rice Fund, the Timber Revenue Account; and Liberian dollar GoL/CBL Civil Servant Payroll Account No.2, and the GoL General Account. Any new accounts opened by the GoL at the CBL or at any other local financial agency shall be 
reported to the IMF also. For the purposes of measurement, all holdings in Liberian dollars accounts will be converted at the end of period exchange rate.

6. Noncash tax/duty payment is defined as any noncash settlement of duty/tax obligations to the GoL through the exchange of goods or services.

7. New domestic borrowing is defined as new claims on the central government since the start of the program. It will be measured by the change in the stock of all outstanding claims on the central government (loans, advances, and any government debt instruments, such as long-term government securities) by the banking system. The definition also includes the issuance of debt instruments by the GoL to the nonbank sector. For the purposes of measurement, all claims in Liberian dollars will be converted at the end of period exchange rate.

8. New domestic arrears/payables of the government are calculated as the difference between government payment commitments and the actual payments made on such commitments, providing for a processing period of no more than 15 days from the date of commitment. Actual payments are defined as having taken place on the date of issuance of the checks by the Ministry of Finance. Government payment commitments include all expenditure for which commitment vouchers have been officially stamped with the Bureau of General Accounting (BGA) seal, and other non-discretionary expenditure that are now automatically approved, namely, wages and salaries, pensions, capital notes, and CBL bank charges.

9. Contracting or guaranteeing of new external debt by the public sector. For the purposes of the program, external debt applies not only to the meaning set forth in point No. 9 of the "Guidelines on Performance Criteria with Respect to Foreign Debt" ( see Decision No. 12274-00/85, August 24, 2000 attached in Annex I), but also to commitments contracted or guaranteed for which value has not been received. In this memorandum, the public sector consists of the central and state-owned enterprises, including the CBL.

10. The CBL's expenses are defined as the sum of (i) recurrent expenditures and (ii) capital expenditure, on a cash basis.

11. Payment arrears of the CBL are calculated as the difference between payments due on commitments from the start of the program and actual payments made on those commitments. For the purpose of this memorandum, the CBL's commitments due include all expenditure for which goods and services have been delivered but have not been paid for.

12. The CBL's cash-based budget balance is defined as the difference between (a) total revenues (the sum of interest income and non-interest income) on a cash basis; and (b) total current expenditure plus capital expenditure, on a cash basis.

13. The CBL's net foreign exchange position is defined as the difference between (a) the CBL's gross foreign liquid assets, as currently defined in the monthly monetary survey and (b) the sum of its gross foreign liquid liabilities and liquid liabilities denominated in US dollars, as currently defined in the monthly monetary survey. 
14. The token payments to the IMF are defined as monthly payments to the IMF. These payments shall, unless otherwise instructed by the GoL, be applied to the oldest maturing General Resources Account debt obligations owed by Liberia to the IMF. The IMF reserves the right to request the authorities to deposit payments into an escrow account established at another institution overseas.

\section{Program Monitoring}

\section{A. Program-Monitoring Committee}

15. The Liberian authorities shall maintain a program-monitoring committee composed of senior officials from the Ministry of Finance, the CBL, and other relevant agencies. The IMF Resident Representative will have observer status on this committee. The committee shall be responsible for monitoring the performance of the program, recommending policy responses, informing the IMF regularly about the progress of the program, and transmitting the supporting materials necessary for the evaluation of benchmarks. The committee shall provide the IMF with a progress report on the program on a monthly basis within four weeks of the end of each month, using the latest available data.

\section{B. Data Reporting to the IMF}

16. To allow monitoring of developments under the program, the Ministry of Finance will coordinate and regularly report the following information to the staff of the IMF:

- Detailed reports on monthly revenue and expenditure by budget line and a completed summary table on central government operations (monthly, within three weeks after the end of the month);

- Outstanding appropriations, allotments and commitments, and disbursements for line ministries and agencies (monthly, within three weeks after the end of the month);

- Disbursements of budget support grants and loans, by donor (monthly, within two weeks after the end of the month);

- Daily balances in the GoL accounts at the CBL. These comprise the US dollar: GoL General Account No. 2, the GoL Special Rice Fund, the Timber Revenue Account; and Liberian dollar accounts: the GoL/CBL Civil Servant Payroll Account No.2, and the GoL General Account. Any new accounts opened by the GoL at the CBL or at any other local financial agency shall be reported to the IMF also (daily, within three days from the date of the statement); 
- A table providing the end-of-period stock of domestic arrears accumulated and payments made on arrears during the program period, by budget category (wages, goods and services, etc) (monthly, within four weeks after the end of the month);

- The amount of new domestic debt contracted or guaranteed by the public sector (monthly, within two weeks after the end of the month);

- The amount of new external debt contracted or guaranteed by the public sector (monthly, within two weeks after the end of the month);

- The balance sheet of the CBL in the monthly monetary survey, (monthly, within three weeks after the end of the month);

- The full monthly monetary survey of the monetary sector, (monthly, within six weeks after the end of the month);

- The core set of financial soundness indicators, including the overall profitability of the banking sector (quarterly, within three weeks after the end of the quarter);

- The monthly reports on CBL cash revenues and expenditures in US dollar and Liberian dollar terms, on an aggregated basis (including both recurrent and capital expenditure) (monthly, within three weeks after the end of the month);

- Outstanding commitments and disbursements of the CBL expenses (monthly, within three weeks after the end of the month);

- The detailed report on foreign exchange auctions and the CBL's direct foreign exchange transactions with the government, including amount, date, and rate (monthly, within three weeks after the end of the month);

- Indicators of overall economic trends, including the monthly consumer price index, the monthly harmonized consumer prices index, daily foreign exchange rates and interest rates, monthly trade data, monthly imports of petroleum products, commercial bank inflows and outflows, production data (monthly, within six weeks after the end of the month);

- A report on the status of implementation of the structural performance criteria and benchmarks specified in Table 2 of the MEFP (monthly, within two weeks after the end of the month).

17. The above data and reports will be provided in hard copies and electronically to the IMF Resident Representative to Liberia (Mr. Tharkur) for further transfer to the African Department of the IMF in Washington, D.C. 


\section{Annex 1: Guidelines on Performance Criteria with Respect to Foreign Debt}

Excerpt from Executive Board Decision No. 6230-(79/140), as revised on August 24, 2000

(a) For the purpose of this guideline, the term "debt" will be understood to mean a current, i.e., not contingent, liability, created under a contractual arrangement through the provision of value in the form of assets (including currency) or services, and which requires the obligor to make one or more payments in the form of assets (including currency) or services, at some future point(s) in time; these payments will discharge the principal and/or interest liabilities incurred under the contract. Debts can take a number of forms, the primary ones being as follows:

(i) loans, i.e., advances of money to the obligor by the lender made on the basis of an undertaking that the obligor will repay the funds in the future (including deposits, bonds, debentures, commercial loans and buyers' credits) and temporary exchanges of assets that are equivalent to fully collateralized loans under which the obligor is required to repay the funds, and usually pay interest, by repurchasing the collateral from the buyer in the future (such as repurchase agreements and official swap arrangements);

(ii) suppliers' credits, i.e., contracts where the supplier permits the obligor to defer payments until some time after the date on which the goods are delivered or services are provided; and

(iii) leases, i.e., arrangements under which property is provided which the lessee has the right to use for one or more specified period(s) of time that are usually shorter than the total expected service life of the property, while the lesser retains the title to the property. For the purpose of the guideline, the debt is the present value (at the inception of the lease) of all lease payments expected to be made during the period of the agreement excluding those payments that cover the operation, repair or maintenance of the property.

(b) Under the definition of debt set out in point 9 (a) above, arrears, penalties, and judicially awarded damages arising from the failure to make payment under a contractual obligation that constitutes debt are debt. Failure to make payment on an obligation that is not considered debt under this definition (e.g., payment on delivery) will not give rise to debt. 
INTERNATIONAL MONETARY FUND

LIBERIA

\section{Second Review of Performance Under the Staff-Monitored Program and Program for 2007-Informational Annex}

Prepared by the African Department

(In collaboration with other departments)

Approved by David Andrews and Matthew Fisher

January 18,2007

- $\quad$ Relations with the Fund. Describes financial and technical assistance by the IMF and provides information on the safeguards assessment and exchange system. Liberia has been in continuous arrears to the Fund since 1984. The Fund issued a declaration of noncooperation in 1990, and Liberia's voting rights were suspended in March 2003. Liberia's arrears to the Fund at endNovember 2006 amounted to SDR 528 million (740 percent of quota). The authorities have been making monthly token payments of US $\$ 60,000$ to the Fund since November 2005, up from US $\$ 50,000$ since January 2004. On October 2, 2006, the Executive Board lifted the declaration of noncooperation, and initiated the process of de-escalating the remedial measures the Fund has been applying against Liberia.

- $\quad$ Relations with the World Bank. Describes World Bank Group program and portfolio.

- $\quad$ Statistical Issues. Assesses the quality of statistical data. Substantial weaknesses in Liberia's economic statistics hamper effective surveillance, largely because the civil war caused widespread destruction of databases and the loss of administrative and institutional capacity for statistics. 


\section{Liberia-APPendices to the SECONd ReVieW OF PeRformance Under} The Staff-Monitored Program ANd Program For 2007

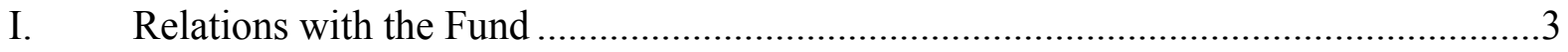

II. Relations with the World Bank Group............................................................. 6

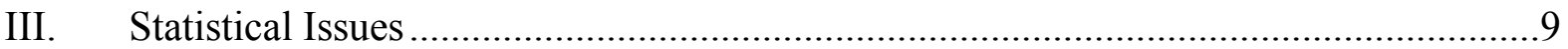




\section{Appendix I. Liberia-Relations with the Fund}

(As of November 30, 2006)

I. Membership Status: Joined 03/28/1962; Article XIV
II. General Resources Account:
Quota
Fund holdings of currency
Reserve position in Fund

III. SDR Department:

Net cumulative allocation

Holdings

IV. Outstanding Purchases and Loans:

Stand-By Arrangements

Contingency and Compensatory

Trust Fund
SDR Million

71.3

271.6

0.0

SDR Million

21.0

0.0

SDR Million

165.6

34.7

22.9
\% Quota

100.0

380.9

0.0
\% Allocation
100.0
0.0

\% Quota

232.2

48.7

32.1

V. Latest Financial Arrangements:

\begin{tabular}{|c|c|c|c|c|}
\hline Type & $\begin{array}{r}\text { Approval } \\
\text { Date }\end{array}$ & $\begin{array}{r}\text { Expiration } \\
\text { Date }\end{array}$ & $\begin{array}{c}\text { Amount } \\
\text { Approved } \\
\text { (SDR Million) }\end{array}$ & $\begin{array}{r}\text { Amount } \\
\text { Drawn } \\
\text { (SDR Million) } \\
\end{array}$ \\
\hline Stand-By & $12 / 07 / 1984$ & $12 / 06 / 1985$ & 42.8 & 8.5 \\
\hline Stand-By & $09 / 14 / 1983$ & 09/13/1984 & 55.0 & 55.0 \\
\hline
\end{tabular}

VI. Projected Obligations to the Fund ${ }^{17}$ (SDR million; based on existing use of resources and present holdings of SDRs):

Principal

Charges/interest

Total

$\frac{\text { Overdue }}{11 / 30 / 2006}$
223.18
$\frac{304.55}{527.73}$

\begin{tabular}{lcccc}
\multicolumn{5}{c}{ Forthcoming } \\
2006 & 2007 & 2008 & 2009 & 2010 \\
$\underline{0.06}$ & $\frac{12.96}{12.96}$ & $\frac{12.97}{12.97}$ & $\frac{12.95}{12.95}$ & 12.96 \\
\hline 0.06 & 12.96
\end{tabular}

\footnotetext{
${ }^{1}$ The projection of charges and interest assumes that overdue principal at the report date (if any) will remain outstanding, but that forthcoming obligations will be settled on time.
} 


\section{Safeguards Assessment}

A safeguards assessment mission visited Liberia in October 2006. The mission found that steps have been taken to implement overall controls in the CBL, but vulnerabilities exist in most areas of the safeguards framework, including in financial reporting, and internal and external audit. However, an audit of the CBL's 2006 accounts is currently being conducted by Ernst \& Young. A follow up mission to complete the safeguards assessment will be needed to meet the requirement under a potential rights accumulation program (RAP).

\section{Exchange Rate Arrangement}

The currency of Liberia is the Liberian dollar. The U.S. dollar is also legal tender. The current exchange rate arrangement is a managed float, with no predetermined path for the exchange rate. The exchange rate of the Liberian dollar is market determined, and all foreign exchange dealers, including banks, are permitted to buy and sell currencies, including the U.S. dollar. Liberia's exchange rate at end-November 2006 was L\$57.0=US\$1.

\section{Article IV Consultation}

The 2006 Article IV consultation discussions were held in Monrovia during February 16March 1, 2006 in Monrovia. The staff report (Country Report No. 06/166, 5/08/06) was discussed by the Executive Board on April 26, 2006 and is posted on the IMF website.

\section{Technical Assistance}

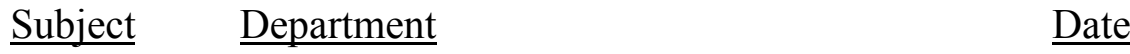

Mission: assessment of TA needs

Mission: monetary operations, foreign

exchange, auctions, banking supervision, payments system

Mission: monetary operations, foreign exchange auctions, banking supervision, payments system

Mission: monetary operations, foreign exchange auctions, payments system

Mission: bank restructuring Mission: monetary operations, foreign exchange auctions, banking supervision, payments system

Mission: negotiation on chief administrator post MFD

Chief Administrator for the CBL
MFD

MFD

Dec. 2003

May 2004

MFD

Aug. 2004

MFD

Feb. 2005

MFD

May 2005

MFD

Aug. 2005

MFD long-term
Dec. 2005

Feb. 2006 
Mission: bank restructuring, monetary operations, payment systems, and central bank accounting

MFD

$\mathrm{MCM}$

$\mathrm{MCM}$

$\mathrm{MCM}$

FAD

FAD

FAD

FAD

FAD

FAD

FAD

FAD

FAD

FAD

FAD

FAD

FAD

FAD short-term

FAD long-term

STA

STA

STA

STA

STA

STA

STA

STA

STA

STA

STA

LEG
June 2006

Aug. 2006

Aug. 2006

Oct. 2006

Dec. 2003

May 2004

July 2004

Sep. 2004

Dec. 2004

Feb. 2005

Feb. 2005

May 2005

Dec. 2005

Feb. 2006

Mar. 2006

May 2006

Aug. 2006

Oct. 2006

Nov. 2006

Dec. 2003

May 2004

July 2004

July 2004

July 2004

Aug. 2004

Jan. 2006

May 2006

June 2006

Nov. 2006

Nov. 2006

Oct. 2006

\section{Resident Representative}

A resident representative has been posted in Monrovia since April 2, 2006. 


\section{Appendix II. Liberia-Relations with the World Bank Group}

(As of November 30, 2006,)

The World Bank suspended disbursements to Liberia in December 1986 as a result of mounting arrears, and Liberia's loans were placed in nonaccrual status in June 1987. To that date, disbursements had totaled US\$141.3 million from 22 IBRD loans and US\$91.5 million from 17 IDA credits; only US\$ 43.6 million owing on these disbursements has been repaid. By November 30, 2006, Liberia's arrears to the World Bank were US\$465.2 million (of which US\$49.6 million to IDA and US\$465.2 million to IBRD), reflecting further interest charges. Since June 20, 2006, Liberia has received two pre-arrears clearance IDA grants totaling US\$46.5 million to meet emergency infrastructure needs. Liberia has an outstanding obligation of US\$2.2 million to the World Bank, since August 24, 2005, to fulfill the Maintenance of Value (MOV) clause in the Bank's Articles of Agreement.

\section{The Bank Group strategy and lending operations}

Following the Comprehensive Peace Agreement in August 2003 and the installation of the National Transitional Government of Liberia (NTGL) in October 2003, the Bank co-hosted with the UN and US the International Reconstruction Conference for Liberia in February 2004. In March 2004, the Executive Directors of the Bank discussed the Liberia Country Reengagement Note. In April 2004 a US\$4.0 million grant from the Bank’s newly created LICUS Implementation Trust Fund was approved to fund activities in four areas: community empowerment, including a rapid social assessment; public procurement and financial management; forestry sector management; and the coordination and implementation of the Results-Focused Transition Framework (RFTF). A US\$25 million grant from the Bank's IBRD surplus, was endorsed by the Bank's Executive Directors in August 2004 and approved by the Bank's Board of Governors in October 2004. This grant extends funding of the above activities, funds additional activities in the area of infrastructure, public procurement and financial management, and provides support for the internationally supported Governance and Economic Management Assistance Program (GEMAP) agreed to with the NTGL in September 2005. Support for distance learning is being prepared.

In addition to the trust-funded operations mentioned above, the Bank has prepared its first IDA operation for Liberia, the Liberia Emergency Infrastructure Pre-Arrears Clearance Grant of US\$30.0 million which was approved by the Bank's Board on June 20, 2006. This grant will focus on the reconstruction of two primary roads, construction of 6 major bridges and the repair of an additional 65, restoration of a water treatment plant, and support for the reestablishment of power in Monrovia as well as on strengthening institutional capacity within the Ministry of Public Works to manage the above activities.

Future Bank assistance to Liberia will be defined within the context of a new Interim Strategy Note (ISN) under preparation. 
Area of Structural Reform

\section{Fiscal area}

Civil service reform

Expenditure monitoring and control

Public Expenditure and Financial Accountability

Tax administration, policy and legislation

\section{Monetary and Financial sector}

Banking sector reform

Technical Assistance (Central Bank)

\section{Governance}

GEMAP

Extractive Industries Transparency Initiative (EITI)

Kimberly Process

\section{Private sector development}

Business climate

Forestry and mining sector reform

\section{Other}

Price controls

External trade

Transport

Urban development

Decentralization

\section{Lead Institution}

The World Bank

IMF

World Bank

IMF

IMF/World Bank

IMF/World Bank

The World Bank/IMF

World Bank

World Bank

World Bank

World Bank

IMF

IMF

World Bank

World Bank

World Bank

\section{IMF-World Bank collaboration in specific areas}

Overall, the IMF and World Bank staffs maintain a close collaboration in policy advice to the Liberian authorities. In view of the structural measures envisaged under the medium term program, successful implementation hinges on complementary action by the World Bank, especially in the areas of business climate improvements, poverty reduction policies, and nonrenewable resource management.

\section{Areas in which the World Bank leads and there is no direct IMF involvement}

The Bank is supporting the preparation of the Poverty Reduction Strategy, and in that context, will continue to provide support for strengthening the statistical capacity and assist the NSO (National Statistical Office) to undertaking key household surveys along the lines of the CWIQ (Core Welfare Indicators Questionnaire) to updating key social indicators to be monitored on annual basis. The Bank plans to assist the NSO in putting together a monitoring and evaluation system for the PRS. 


\section{Areas in which the World Bank leads and its analysis serves as input into the IMF.}

The World Bank will consider undertaking PEFA (Public Expenditure and Financial Accountability) analysis to assist the national authorities strengthen their ability to (i) diagnose the condition of country public expenditure, procurement and financial accountability systems, and (ii) develop a practical sequence of reform and capacity-building actions, in a manner that encourages country ownership, reduces the transaction costs, enhance donor harmonization and better addresses developmental and fiduciary concerns leading to improved impact of reforms.

Areas where the Fund takes the lead role and its analysis serves as input into the World Bank-supported program are in the dialogue on fiscal matters, which sets the overall envelope for public expenditures. The IMF is also providing technical assistance in the area of revenue administration.

The IMF leads the dialogue on policies to contain various expenditures in the public sector. These include policies regarding the wage bill in the public sector and the definition of the ceiling for public investment expenditures. In these areas, the Bank takes into account the policy recommendations of the IMF and ensures that its own policy advice is consistent.

Areas in which the IMF leads, and there is no direct World Bank involvement relate to the dialogue on monetary policy, interest rates, the exchange rate, the balance of payments, and related statistical and measurement issues.

\begin{tabular}{|c|c|c|c|c|}
\hline \multicolumn{5}{|c|}{$\begin{array}{l}\text { World Bank Group } \\
\text { Statement of Loans/Credits/Grants for Liberia } \\
\text { Summary in U.S. Dollars at November 30, } 2006\end{array}$} \\
\hline & IBRD & IDA Credits & IDA Grants & Total \\
\hline Original Principal & $155,950,000$ & $114,500,000$ & $46,500,000$ & $316,950,000$ \\
\hline Cancellations & $14,693,265$ & $22,765,012$ & 0 & $37,458,277$ \\
\hline Disbursed & $141,256,735$ & $91,541,498$ & $1,133,956$ & $233,932,190$ \\
\hline Undisbursed & 0 & 0 & $46,700,653$ & $46,700,653$ \\
\hline Repaid & $42,874,104$ & 723,744 & 0 & $43,597,848$ \\
\hline Due & $97,977,632$ & $108,927,871$ & 0 & $206,905,502$ \\
\hline Exchange Adjustment & $55,092,430$ & 0 & 0 & $55,092,430$ \\
\hline Borrower Obligation & $153,070,061$ & $108,927,871$ & 0 & $261,997,932$ \\
\hline
\end{tabular}

World Bank, Integrated Controller's System.

Contact person at World Bank: Michael Diliberti 202-473-8766. 


\section{Appendix III. Liberia-Statistical Issues}

18. Substantial weaknesses in Liberia's economic statistics hamper effective surveillance, largely because the civil war caused widespread destruction of databases and the loss of administrative and institutional capacity. Several STA missions have visited Monrovia in recent years (five in 2006) to assist the authorities in rebuilding capacity to compile statistics in the areas of national accounts, price, monetary, fiscal and balance of payments statistics.

19. The government passed legislation in July 2004 to create the Liberia Institute of Statistics and Geo-Information Services (LISGIS) as a semi-autonomous agency. This agency will have the lead in coordinating and reestablishing national economic and social statistics.

20. As one of fifteen countries participating in the Fund's General Data Dissemination System (GDDS) Project for Anglophone African Countries (funded by the U.K. Department for International Development), Liberia has undertaken to use the GDDS as a framework to develop its national statistical system. Metadata and plans for improving the data over the short and medium term were posted on the Fund's Dissemination Standards Bulletin Board (DSBB) on December 8, 2006.

21. The Central Bank of Liberia (CBL) is now regularly reporting monetary and financial and exchange rate statistics for publication in International Financial Statistics (IFS), but their quality and timeliness need to be improved. The CBL also publishes data on money and banking, prices and output, fiscal operations and debt, interest and exchange rates, and foreign trade in its statistical bulletin, Liberia Financial Statistics, on a bimonthly basis with a lag of about six months. It also publishes the quarterly Financial and Economic Bulletin, covering the previous four quarters, with a lag of about six months.

\section{Real sector}

22. Annual estimates of production by sector are prepared by the National Accounts Unit of the Ministry of Planning and Economic Affairs (MPEA). The Fund staff has estimated total GDP by sectoral origin for the period 1997-2005 with the assistance of the MPEA. National accounts data would benefit from: (i) establishment of a national business register; and (ii) resumption of an annual Establishment Survey and National Accounts Questionnaire for manufacturing, mining, utilizes and agriculture. Estimates for GDP by expenditure are not available. A Household Income and Expenditure Survey is required as a base for more reliable data.

\section{Prices}

23. The Price Unit of the MPEA began producing a consumer price index in late 1998, with May 1998 as the start date and reference period. However, the weights are based on an expenditure survey of 100 Monrovia households conducted in 1963-64. Targeted sampling 
frequencies vary from bimonthly for food items to biannually for rents and personal care and services, and often fall behind schedule. A survey conducted in June 2004 updated two subgroups of expenditure — rent and personal care and health services — which are included in the Monrovia consumer price index. Monthly data have been reported to the Fund in tandem with publication, which generally involves a lag of about two months.

24. The authorities are considering recent STA recommendations to replace the Monrovia Consumer Price Index with a Harmonized Consumer Price Index (HCPI), which is based on an expanded basket of goods and services consistent with the ECOWAS harmonized market basket, and updated weights (using consumption patterns in neighboring countries in the absence of an updated household survey). The authorities have compiled data since February 2006, and will begin formally using the HCPI in January 2007.

\section{Government finance statistics}

25. The authorities regularly provide staff with information on fiscal accounts on a cash basis. The Ministry of Finance (MoF) provides monthly disaggregated data on government revenue and on current and capital expenditure. There is considerable scope, however, for improving the quality and consistency of the government finance statistics, including reporting fiscal data on both a cash and a commitment basis. Data on domestic arrears and on financing items are unreliable. Although Liberia has availed itself of substantial technical assistance under the DFID project for Anglophone Africa, the authorities have not reported data for publication in the Government Financial Statistics Yearbook (GFSY) since 1988, or for the IFS for several years. The authorities have begun efforts to move to the GFSM 2001.

\section{Monetary statistics}

26. The CBL has made progress in compiling monetary aggregates according to international standards. However, further steps are needed to strengthen the CBL's accounting system, including properly accounting for foreign reserves and appropriately segregating required reserves by currency denomination and classification of other assets and liabilities. In addition, while the reporting of preliminary statistics by commercial banks has improved, the response by banks to requests for explanations and follow-up to noted inconsistencies continues to be weak. An STA mission in November 2006 finalized the standardized report form (SRF) for the $\mathrm{CBL}$ and recommended creation of an integrated monetary database to allow for improved monetary policy design and implementation.

\section{Balance of payments and external debt}

27. Official balance of payments statistics have not been reported comprehensively since the 1988 Article IV consultation; however, the Fund staff has prepared provisional balance of payments statistics in cooperation with the CBL, the Ministry of Commerce (MoC), MPEA, and the Ministry of Finance (MoF). The CBL is responsible for compiling the balance of payments in coordination with other agencies. Some progress has been made in compiling 
certain current and financial account components - mainly on trade and related services, government expenditures, remittances, and on nonresident deposits in the financial accountbut lack of primary source data and errors in distinguishing between components in services, income and transfers underscore the need for technical assistance in the area of capacity building. A stronger effort must be made to resolve and reconcile the significant discrepancies in trade data reported by the various agencies. The CBL has completed a census of foreign direct investment enterprises in preparation for an investment survey following the recommendations made by the STA mission in July 2004.

28. Significant gaps exist in the records of external public debt, particularly those related to bilateral and commercial creditors. An STA balance of payments technical assistance mission visited Monrovia in November 2006 and identified inadequate staffing and poor coordination with data providers as key impediments to improving balance of payments statistics for Liberia. A task force comprising staff seconded from the CBL, MoF, MPEA, General Auditing Office (GAO) and the Bureau of the Budget (BoB) is making progress in obtaining loan agreements and financial statements from external creditors to update the external debt database maintained by the MoF. As part of building capacity for balance of payments and external debt statistics compilation, STA trained three Liberian officials in 2005 - one in balance of payments and two in debt statistics. The authorities have also engaged the services of an international financial advisor to assist with rebuilding the database on external commercial debt. 


\section{Liberia-Table of Common Indicators Required for Surveillance}

As of December 31, 2006

\begin{tabular}{|c|c|c|c|c|c|}
\hline & $\begin{array}{c}\text { Date of } \\
\text { latest } \\
\text { observation }\end{array}$ & $\begin{array}{l}\text { Date } \\
\text { received }\end{array}$ & $\begin{array}{l}\text { Frequency } \\
\text { of Data }^{4}\end{array}$ & $\begin{array}{l}\text { Frequency } \\
\text { of } \\
\text { Reporting }^{4}\end{array}$ & $\begin{array}{l}\text { Frequency } \\
\text { of } \\
\text { publication }^{4}\end{array}$ \\
\hline Exchange Rates & Nov. 2006 & Dec. 2006 & $\mathrm{D}$ & M & B \\
\hline $\begin{array}{l}\text { International Reserve Assets and } \\
\text { Reserve Liabilities of the Monetary } \\
\text { Authorities }{ }^{1}\end{array}$ & Nov. 2006 & Dec. 2006 & M & M & B \\
\hline Reserve/Base Money & Nov. 2006 & Dec. 2006 & M & M & $\mathrm{B}$ \\
\hline Broad Money & Oct. 2006 & Dec. 2006 & M & M & $\mathrm{B}$ \\
\hline Central Bank Balance Sheet & Nov. 2006 & Dec. 2006 & M & M & B \\
\hline $\begin{array}{l}\text { Consolidated Balance Sheet of the } \\
\text { Banking System }\end{array}$ & Oct. 2006 & Dec. 2006 & M & M & B \\
\hline Interest Rates & Sep. 2006 & Dec. 2006 & M & M & $\mathrm{B}$ \\
\hline Consumer Price Index & Oct. 2006 & Nov 2006 & M & M & B \\
\hline $\begin{array}{l}\text { Revenue, Expenditure, Balance and } \\
\text { Composition of Financing }{ }^{2}- \\
\text { General Government }^{3}\end{array}$ & $\ldots$ & $\ldots$ & $\ldots$ & $\ldots$ & $\ldots$ \\
\hline $\begin{array}{l}\text { Revenue, Expenditure, Balance and } \\
\text { Composition of Financing }{ }^{2}-\text { Central } \\
\text { Government }\end{array}$ & Oct. 2006 & Nov. 2006 & M & M & $\mathrm{B}$ \\
\hline $\begin{array}{l}\text { Stocks of Central Government and } \\
\text { Central Government-Guaranteed } \\
\text { Debt }\end{array}$ & Mar. 2006 & May. 2006 & Q & $\mathrm{B}$ & B \\
\hline External Current Account Balance & $\ldots$ & $\ldots$ & $\ldots$ & $\ldots$ & $\ldots$ \\
\hline $\begin{array}{l}\text { Exports and Imports of Goods and } \\
\text { Services }\end{array}$ & Oct. 2005 & Dec. 2005 & M & Q & $\mathrm{B}$ \\
\hline GDP/GNP & $\ldots$ & $\ldots$ & $\ldots$ & $\ldots$ & $\ldots$ \\
\hline Gross External Debt & Mar. 2005 & May. 2006 & Q & $\mathrm{B}$ & B \\
\hline
\end{tabular}

${ }^{1}$ Includes reserve assets pledged or otherwise encumbered.

${ }^{2}$ Foreign, domestic bank, and domestic nonbank financing.

${ }^{3}$ The general government consists of the central government (budgetary funds, extrabudgetary funds, and social security funds) and state and local governments.

${ }^{4}$ Daily (D); Weekly (W); Monthly (M); Bi-monthly (B); Quarterly (Q); Annually (A); Irregular (I); Not Available (NA) 